\title{
Constitutive Activity and Ligand Selectivity of Human, Guinea Pig, Rat, and Canine Histamine $\mathrm{H}_{2}$ Receptors
}

\author{
Hendrik Preuss, Prasanta Ghorai, ${ }^{1}$ Anja Kraus, Stefan Dove, Armin Buschauer, \\ and Roland Seifert
}

Department of Pharmaceutical/Medicinal Chemistry II, Institute of Pharmacy, University of Regensburg, Regensburg, Germany (H.P., P.G., A.K., S.D., A.B.); and Department of Pharmacology and Toxicology, Institute of Pharmacy, University of Regensburg, Regensburg, Germany (R.S.)

Received January 16, 2007; accepted February 28, 2007

\begin{abstract}
Previous studies revealed pharmacological differences between human and guinea pig histamine $\mathrm{H}_{2}$ receptors $\left(\mathrm{H}_{2} R \mathrm{Rs}\right)$ with respect to the interaction with guanidine-type agonists. Because $\mathrm{H}_{2} \mathrm{R}$ species variants are structurally very similar, comparative studies are suited to relate different properties of $\mathrm{H}_{2} \mathrm{R}$ species isoforms to few molecular determinants. Therefore, we systematically compared $\mathrm{H}_{2} \mathrm{Rs}$ of human (h), guinea pig (gp), rat (r), and canine (c). Fusion proteins of $\mathrm{hH}_{2} \mathrm{R}, \mathrm{gpH} \mathrm{H}_{2} \mathrm{R}$, $\mathrm{rH}_{2} \mathrm{R}$, and $\mathrm{CH}_{2} \mathrm{R}$, respectively, and the short splice variant of $\mathrm{G}_{\mathrm{s} \alpha}, \mathrm{G}_{\mathrm{s} \alpha \mathrm{S}}$, were expressed in Sf9 insect cells. In the membrane steady-state GTPase activity assay, $\mathrm{cH}_{2} \mathrm{R}-\mathrm{G}_{\mathrm{s} \alpha \mathrm{s}}$ but neither $\mathrm{gpH}_{2} \mathrm{R}-\mathrm{G}_{\mathrm{s} \alpha \mathrm{S}}$ nor $\mathrm{rH}_{2} \mathrm{R}-\mathrm{G}_{\mathrm{s} \alpha \mathrm{S}}$ showed the hallmarks of increased constitutive activity compared with $\mathrm{hH}_{2} R-\mathrm{G}_{\mathrm{s} \alpha \mathrm{S}}$, i.e., increased efficacies of partial agonists, increased potencies of agonists
\end{abstract}

with the extent of potency increase being correlated with the corresponding efficacies at $\mathrm{hH}_{2} \mathrm{R}-\mathrm{G}_{\mathrm{s} \alpha \mathrm{S}}$, increased inverse agonist efficacies, and decreased potencies of antagonists. Furthermore, in membranes expressing nonfused $\mathrm{H}_{2} \mathrm{Rs}$ without or together with mammalian $\mathrm{G}_{\mathrm{s} \alpha \mathrm{S}}$ or $\mathrm{H}_{2} \mathrm{R}-\mathrm{G}_{\mathrm{s} \alpha}$ fusion proteins, the highest basal and GTP-dependent increases in adenylyl cyclase activity were observed for $\mathrm{CH}_{2} \mathrm{R}$. An example of ligand selectivity is given by metiamide, acting as an inverse agonist at $h \mathrm{H}_{2} \mathrm{R}-\mathrm{G}_{\mathrm{s} \alpha \mathrm{S}}, \mathrm{gpH}_{2} \mathrm{R}-\mathrm{G}_{\mathrm{s} \alpha \mathrm{S}}$, and $\mathrm{rH}_{2} \mathrm{R}-\mathrm{G}_{\mathrm{s} \alpha \mathrm{S}}$ in the GTPase assay in contrast to being a weak partial agonist with decreased potency at $\mathrm{cH}_{2} \mathrm{R}-\mathrm{G}_{\mathrm{s} \alpha \mathrm{S}}$. In conclusion, the $\mathrm{CH}_{2} \mathrm{R}$ exhibits increased constitutive activity compared with $\mathrm{hH}_{2} \mathrm{R}, \mathrm{gpH}_{2} \mathrm{R}$, and $\mathrm{rH}_{2} \mathrm{R}$, and there is evidence for ligand-specific conformations in $\mathrm{H}_{2} \mathrm{R}$ species isoforms.
The histamine $\mathrm{H}_{2}$ receptor $\left(\mathrm{H}_{2} \mathrm{R}\right)$ species isoforms of canine (Gantz et al., 1991b), human (Gantz et al., 1991a), rat (Ruat et al., 1991), and guinea pig (Traiffort et al., 1995) were cloned. The four $\mathrm{H}_{2} \mathrm{R}$ species isoforms are closely related to each other, as is reflected by an overall amino acid sequence identity of more than $80 \%$. The highest conservation exists within the seven $\alpha$-helical transmembrane (TM) domains

This work was supported by the Research Training Program (Graduiertenkolleg) GRK 760 "Medicinal Chemistry: Molecular Recognition-Ligand-Receptor Interactions" of the Deutsche Forschungsgemeinschaft.

${ }^{1}$ Current affiliation: Department of Chemistry, University of Nebraska, Lincoln, Nebraska.

Article, publication date, and citation information can be found at http://jpet.aspetjournals.org.

doi:10.1124/jpet.107.120014 (sequence identity of more than $90 \%$ ), whereas the N-terminal domain together with the extracellular end of TM1 and the $\mathrm{C}$ terminus are the least conserved regions (Fig. 1).

Despite this high degree of structural similarity, $N$-[3-( $1 H$ imidazol-4-yl)propyl]guanidines such as compounds $\mathbf{8}$ to $\mathbf{1 0}$ (Fig. 2) differentially activate guinea pig $\left(\mathrm{gpH}_{2} \mathrm{R}\right)$ and human $\left(\mathrm{hH}_{2} \mathrm{R}\right) \mathrm{H}_{2}$ receptors. In a membrane steady-state GTPase activity assay using fusion proteins of $\mathrm{H}_{2} \mathrm{R}$ and the short splice variant of $\mathrm{G}_{\mathrm{s} \alpha}, \mathrm{G}_{\mathrm{s} \alpha \mathrm{S}}$, such $\mathrm{H}_{2} \mathrm{R}$-selective agonists are considerably more potent and efficacious at $\mathrm{gpH}_{2} \mathrm{R}-\mathrm{G}_{\mathrm{s} \alpha \mathrm{S}}$ than at $\mathrm{hH}_{2} \mathrm{R}-\mathrm{G}_{\mathrm{s} \alpha \mathrm{S}}$ (Kelley et al., 2001). By contrast, the small $\mathrm{H}_{2} \mathrm{R}$ agonists histamine (1, HA), dimaprit (2, DIM), amthamine (3, AMT), and betahistine (4, BET) are unselective between these species. Recently, a novel class of $N^{\mathrm{G}}$-acylated imida-

\footnotetext{
ABBREVIATIONS: $\mathrm{H}_{2} R$, histamine $\mathrm{H}_{2}$ receptor; TM, transmembrane domain of a $G$ protein-coupled receptor; $H_{1} R$, histamine $H_{1}$ receptor; gpH $H_{2} R$, guinea pig histamine $\mathrm{H}_{2}$ receptor; $\mathrm{gpH}_{2} \mathrm{R}-\mathrm{G}_{\mathrm{s} \alpha \mathrm{s}}$, fusion protein of the guinea pig histamine $\mathrm{H}_{2}$ receptor and the short splice variant of $\mathrm{G}_{\mathrm{s} \alpha}$; $h \mathrm{H}_{2} \mathrm{R}$, human histamine $\mathrm{H}_{2}$ receptor; $h \mathrm{H}_{2} \mathrm{R}-\mathrm{G}_{\mathrm{s} \alpha \mathrm{S}}$, fusion protein of the human histamine $\mathrm{H}_{2}$ receptor and the short splice variant of $\mathrm{G}_{\mathrm{s} \alpha}$; $\mathrm{G}_{\mathrm{s} \alpha}$, $\alpha$-subunit of the $G_{s}$, protein that mediates adenylyl cyclase activation; $G_{s \alpha S}$, short splice variant of the $G_{s}$ protein $G_{s \alpha}$; HA, histamine; DIM, dimaprit; AMT, amthamine; BET, betahistine; IMP, impromidine; ARP, arpromidine; CIM, cimetidine; RAN, ranitidine; FAM, famotidine; APT, aminopotentidine; IAPT, iodoaminopotentidine; $A C$, adenylyl cyclase; GPCR, G protein-coupled receptor; $\mathrm{rH}_{2} \mathrm{R}$, rat histamine $\mathrm{H}_{2}$ receptor; $r \mathrm{H}_{2} \mathrm{R}-\mathrm{G}_{\mathrm{s} \alpha \mathrm{S}}$, fusion protein of the rat histamine $\mathrm{H}_{2}$ receptor and the short splice variant of $\mathrm{G}_{\mathrm{s} \alpha} ; \mathrm{S}$, signal peptide from influenza hemagglutinin; $F$, FLAG epitope; bp, base pair(s); PAGE, polyacrylamide gel electrophoresis; $\mathrm{cH}_{2} R$, canine histamine $\mathrm{H}_{2}$ receptor; $\mathrm{cH}_{2} \mathrm{R}-\mathrm{G}_{\mathrm{s} \alpha \mathrm{S}}$, fusion protein of the canine histamine $\mathrm{H}_{2}$ receptor and the short splice variant of $\mathrm{G}_{\mathrm{s} \alpha}$; $\mathrm{AR}$, adrenoceptor; ANOVA, analysis of variance.
} 




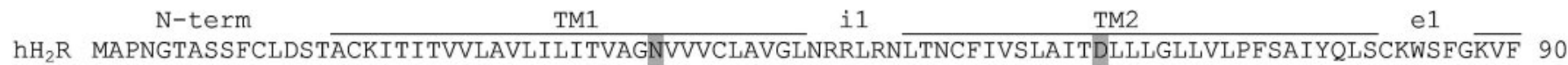

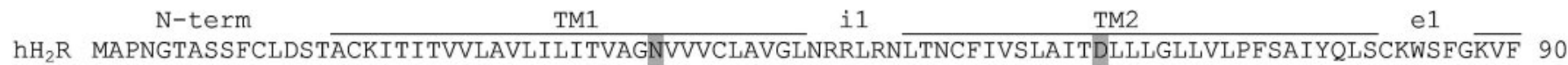

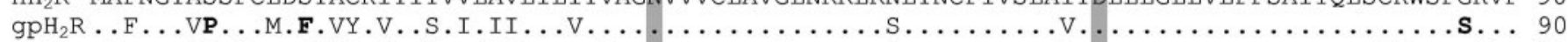

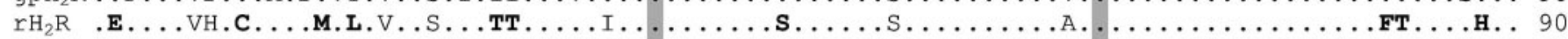

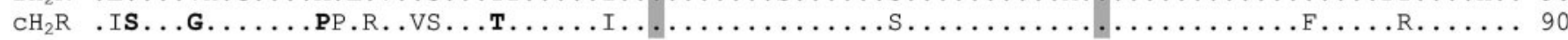

Fig. 1. Comparison of the amino acid sequences of $\mathrm{hH}_{2} \mathrm{R}, \mathrm{gpH}_{2} \mathrm{R}, \mathrm{rH}_{2} \mathrm{R}$, and $\mathrm{cH}_{2} \mathrm{R}$. The amino acid sequences of $\mathrm{hH}_{2} \mathrm{R}, \mathrm{gpH}_{2} \mathrm{R}, \mathrm{rH}_{2} \mathrm{R}$, and $c \mathrm{H}_{2} \mathrm{R}$ are given in the one-letter code. Dots in the sequences of $\mathrm{gpH}_{2} \mathrm{R}, \mathrm{rH}_{2} \mathrm{R}$, and $\mathrm{cH}_{2} \mathrm{R}$ indicate identity with $\mathrm{hH}_{2} \mathrm{R}$. Amino acids shown in white with black shading represent the interaction sites of HA with the $\mathrm{H}_{2} \mathrm{R}$ (Gantz et al., 1992; Nederkoorn et al., 1996). The most conserved residues (X.50 with X being the number of the TM domain, according to the Ballesteros/Weinstein nomenclature) in each TM domain are indicated in gray shading. Amino acids shown in regular font in the sequences of $\mathrm{gpH}_{2} \mathrm{R}, \mathrm{rH}_{2} \mathrm{R}$, and $\mathrm{cH}_{2} \mathrm{R}$ represent conservative exchanges. Amino acids shown in bold in the sequences of $\mathrm{gpH}_{2} \mathrm{R}, \mathrm{rH}_{2} \mathrm{R}$, and $\mathrm{cH}_{2} \mathrm{R}$ represent nonconservative exchanges. $\mathrm{N}$-term, extracellular $\mathrm{N}$-terminal domain of $\mathrm{H}_{2} \mathrm{Rs}$; C-term, intracellular C-terminal domain of $\mathrm{H}_{2} \mathrm{Rs}$; i1, i2, and i3, first, second, and third intracellular loops; e1, e2, e3, first, second, and third extracellular loops, respectively.

zolylpropylguanidines as represented by compounds 11 to 16 was developed (Ghorai, 2005; Xie et al., 2006a). Generally, by introduction of a carbonyl group adjacent to the guanidine moiety, the species selectivity of the agonists is preserved (Xie et al., 2006a). Comparison of the corresponding agonist efficacies in the GTPase assay and at stabilizing the highaffinity ternary complex of the $\mathrm{H}_{2} \mathrm{R}$ with nucleotide-free $\mathrm{G}_{\mathrm{s} \alpha}$ indicate that $N$-[3-(1H-imidazol-4-yl)propyl]guanidines and their $N^{\mathrm{G}}$-acylated analogs stabilize different ligand-specific active conformations of $\mathrm{hH}_{2} \mathrm{R}$ and $\mathrm{gpH}_{2} \mathrm{R}$ (Kelley et al., 2001; Xie et al., 2006a). However, it is not known whether these differences also apply for other $\mathrm{H}_{2} \mathrm{R}$ species isoforms. Moreover, $\mathrm{H}_{2} \mathrm{Rs}$ are known to be constitutively active (Alewijnse et al., 1998), but the degree to which constitutive activity varies among several species isoforms remains elusive. To generate an expanded pharmacological profile of $\mathrm{H}_{2} \mathrm{R}$ species isoforms, in the present report, we compare human, guinea pig, rat, and canine $\mathrm{H}_{2}$ Rs.

Sf9 cell membranes expressing $\mathrm{H}_{2} \mathrm{R}-\mathrm{G}_{\mathrm{s} \alpha \mathrm{S}}$ fusion proteins were used to measure steady-state GTPase activity. For this purpose, we studied several classes of $\mathrm{H}_{2} \mathrm{R}$ ligands (Fig. 2). HA (1) and related small $\mathrm{H}_{2} \mathrm{R}$ agonists DIM (2), AMT (3), and BET (4) similarly interact with the binding site of $\mathrm{H}_{2} \mathrm{R}$. The amino group of HA forms an ionic interaction with Asp98(3.32) in TM3, and the imidazolyl ring presumably interacts with Tyr-182(5.38) and Asp-186(5.42) in TM5 (Fig. 1). The guanidine-type $\mathrm{H}_{2} \mathrm{R}$ agonists impromidine (8, IMP), arpromidine (9, ARP), and BU-E-43 (10), as well as the $N^{\mathrm{G}}$-acylated derivatives 11 to $\mathbf{1 6}$ share a common $N$-[3- $(1 H$ imidazol-4-yl)propyl)]guanidine moiety that mimics binding of HA and thus is crucial for agonistic activity (Dove et al.,
2004). The 2-(5-methylimidazol-4-ylmethylthio)ethyl moiety of IMP and the 3-(4-fluorophenyl)-3-(2-pyridyl)propyl group of ARP are supposed to interact with a pocket formed by multiple residues in TM3, -6 , and -7 (Kelley et al., 2001). The variable side chains of the ARP derivatives $\mathbf{1 0}$ to $\mathbf{1 6}$ consist of diverse mono- or diarylalkyl groups with different chain lengths between the aromatic ring system and the guanidine group. In compound $\mathbf{1 6}$ (Xie et al., 2006b), the aryl ring is replaced by a cyclohexyl moiety. Compound $\mathbf{1 3}$ is the pure $(R)$-enantiomer (eutomer). 2-Benzylhistamine (5) and suprahistaprodifen (6) represent $\mathrm{H}_{1} \mathrm{R}$ agonists with partial $\mathrm{H}_{2} \mathrm{R}$ agonism (Seifert et al., 2003). Burimamide (7) and metiamide (22) are neutral $\mathrm{H}_{2} \mathrm{R}$ antagonists, whereas cimetidine (17, CIM), ranitidine (18, RAN), famotidine (19, FAM), aminopotentidine (20, APT), and iodoaminopotentidine (21, IAPT) act as inverse agonists (Hill et al., 1997; Dove et al., 2004).

Previous studies showed that the determination of adenylyl cyclase (AC) activity in Sf9 cell membranes is a very sensitive system to elucidate differences in the constitutive activities of GPCRs (Seifert et al., 1998b). Therefore, we also assessed AC activity in membranes expressing nonfused $\mathrm{H}_{2} \mathrm{Rs}$ (coupling to endogenous $\mathrm{G}_{\mathrm{s} \alpha}$-like $\mathrm{G}$ proteins), in membranes coexpressing $\mathrm{H}_{2} \mathrm{R}$ and mammalian $\mathrm{G}_{\mathrm{s} \alpha \mathrm{S}}$, and in membranes expressing $\mathrm{H}_{2} \mathrm{R}-\mathrm{G}_{\mathrm{s} \alpha \mathrm{S}}$ fusion proteins.

\section{Materials and Methods}

Materials. The cDNA for the $\mathrm{rH}_{2} \mathrm{R}$ was kindly provided by Dr. $\mathrm{R}$. Leurs (Leiden/Amsterdam Center for Drug Research, Department of Medicinal Chemistry, Vrije Universiteit Amsterdam, Amsterdam, The Netherlands) (Ruat et al., 1991). The cDNA for the $\mathrm{cH}_{2} \mathrm{R}$ was 
<smiles>NCCc1c[nH]cn1</smiles>

1, histamine<smiles>Cc1nc(N)sc1CCN</smiles>

3, amthamine<smiles>NCCc1c[nH]c(Cc2ccccc2)n1</smiles>

5, 2-benzylhistamine<smiles>c1ccc(C(CCc2nc(CCNCCc3c[nH]cn3)c[nH]2)c2ccccc2)cc1</smiles>

6, suprahistaprodifen<smiles>CNC(=S)NCCCCc1c[nH]cn1</smiles>

7, burimamide<smiles>CN(C)CCCSC(=N)N</smiles>

2, dimaprit<smiles>CNCCc1ccccn1</smiles>

4, betahistine<smiles>Cc1[nH]cnc1CSCCNC(=N)NCCCc1c[nH]cn1</smiles>

8, impromidine

<smiles>CN/C(=C/N=O)NCCSCc1ccc(CN(C)C)o1</smiles>

18 , ranitidine

\begin{tabular}{|c|c|c|c|c|c|}
\hline Compd & & $x$ & Y & $\mathbf{R}^{1}$ & $\mathrm{R}^{2}$ \\
\hline 9 & arpromidine & $\mathrm{CH}_{2}$ & $\mathrm{CH}_{2}$ & $4-\mathrm{F}-\mathrm{C}_{6} \mathrm{H}_{4}$ & 2-pyridyl \\
\hline 10 & BU-E-43 & $\mathrm{CH}_{2}$ & $\left(\mathrm{CH}_{2}\right)_{2}$ & phenyl & 2-pyridyl \\
\hline 11, & UR-PG214 & $\mathrm{CO}$ & $\mathrm{CH}_{2}$ & $\mathrm{CH}_{3}$ & 2-thiazolyl \\
\hline 12 & UR-PG215 & $\mathrm{CO}$ & $\mathrm{CH}_{2}$ & phenyl & 2-thiazolyl \\
\hline 13 & UR-PG222A* & $\mathrm{CO}$ & $\mathrm{CH}_{2}$ & $\mathrm{CH}_{3}$ & phenyl \\
\hline 14 & UR-PG123 & $\mathrm{CO}$ & - & phenyl & phenyl \\
\hline 15 & UR-PG136 & $\mathrm{CO}$ & $\mathrm{CH}_{2}$ & $4-\mathrm{F}-\mathrm{C}_{6} \mathrm{H}_{4}$ & 2-pyridyl \\
\hline 16 & UR-AK57 & $\mathrm{CO}$ & $\mathrm{CH}_{2}$ & $\mathrm{CH}_{3}$ & c-hexyl \\
\hline
\end{tabular}<smiles>[R]c1cc(C(=O)NCCNC(=N)NCCCOc2cccc(CN3CCCCC3)c2)ccc1N</smiles>

20,21

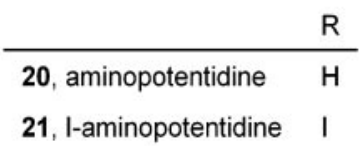<smiles>NC(N)=Nc1nc(CSCCC(N)=NOS(N)(=O)=O)cs1</smiles>

19, famotidine




$\mathrm{H}_{2} \mathrm{R}$ antagonists.

kindly provided by Dr. I. Gantz (University of Michigan, Medical School and Ann Arbor VA Medical Center, Ann Arbor, MI) (Gantz et al., 1991b). The generation of the baculoviruses encoding $\mathrm{hH}_{2} \mathrm{R}$, $\mathrm{gpH}_{2} \mathrm{R}, \mathrm{hH}_{2} \mathrm{R}-\mathrm{G}_{\mathrm{s} \alpha \mathrm{S}}$, and $\mathrm{gpH}_{2} \mathrm{R}-\mathrm{G}_{\mathrm{s} \alpha \mathrm{S}}$ was described previously (Kelley et al., 2001; Houston et al., 2002). The baculoviruses encoding $\mathrm{G}_{\mathrm{s} \alpha \mathrm{S}}$ were kindly provided by Drs. R. Sunahara and A. G. Gilman (Department of Pharmacology, University of Southwestern Medical Center, Dallas, TX). The generation of pGEM-3Z-SF- $\beta_{1} A R-G_{\mathrm{s} \alpha \mathrm{S}}$ and pVL1392-SF- $\beta_{1}$ AR-G $\mathrm{G}_{\mathrm{s} \alpha \mathrm{S}}$ was described previously (Wenzel-Seifert et al., 2002). Compounds 11 through 15 (Ghorai, 2005; Xie et al., 2006a) and compound 16 (Xie et al., 2006b) were prepared as described previously (Ghorai, 2005). The preparation of IMP, ARP, BU-E-43, APT, and IAPT was described previously (Dove et al., 2004). Suprahistaprodifen and 2-benzylhistamine were synthesized as described previously (Elz et al., 2000; Seifert et al., 2003). The structures of compounds were confirmed by analysis $(\mathrm{C}, \mathrm{H}, \mathrm{N}),{ }^{1} \mathrm{H}$ NMR, and mass spectrometry. Purity of compounds was $>98 \%$ as determined by high-performance liquid chromatography or capillary electrophoresis. The anti-FLAG Ig (M1 monoclonal antibody) was from SigmaAldrich (St. Louis, MO). The anti- $\mathrm{G}_{\mathrm{s}} \alpha \mathrm{Ig}$ (C-terminal) was from Santa Cruz Biotechnology (Santa Cruz, CA), and the anti-His ${ }_{6}$ Ig was from Clonetech (Mountain View, CA). $\left[\gamma^{32}{ }^{32} \mathrm{P}\right] \mathrm{GTP}(6000 \mathrm{Ci} /$ mmol), $\left[\alpha{ }^{3}{ }^{32} \mathrm{P}\right] \mathrm{ATP}(800 \mathrm{Ci} / \mathrm{mmol})$, and $\left[{ }^{3} \mathrm{H}\right]$ dihydroalprenolol $(85-90$ $\mathrm{Ci} / \mathrm{mmol}$ ) were from PerkinElmer Life and Analytical Sciences (Boston, MA). All unlabeled nucleotides were from Roche Diagnostics (Indianapolis, IN). HA, BET, CIM, RAN, and FAM were from SigmaAldrich. AMT was from Tocris Cookson Inc. (Ballwin, MO). DIM was from Sigma/RBI (Natick, MA). Burimamide and metiamide were from Dr. W. Schunack (Free University of Berlin, Berlin, Germany). All restriction enzymes, T4 DNA ligase, and calf intestinal phosphatase were from New England Biolabs (Beverly, MA). Cloned Pfu DNA polymerase was from Stratagene (La Jolla, CA).

Construction of the cDNAs for $\mathbf{r H}_{2} \mathbf{R}$ and $\mathbf{r H}_{2} \mathbf{R}-\mathrm{G}_{\mathbf{s} \alpha \mathrm{S}}$. The cDNAs encoding for the proteins were generated by sequential overlap-extension PCRs. With pGEM-3Z-SF- $\mathrm{gpH}_{2} \mathrm{R}-\mathrm{G}_{\mathrm{s} \alpha \mathrm{S}}$ as template, PCR 1A was used to amplify a DNA fragment consisting of the cleavable signal peptide from influenza hemagglutinin (S), the FLAG epitope (F) recognized by the M1 monoclonal antibody, and the start codon of the $\mathrm{rH}_{2} \mathrm{R}$. The sense primer annealed with $18 \mathrm{bp}$ of pGEM-3Z before the $5^{\prime}$ end of SF. The antisense primer annealed with $15 \mathrm{bp}$ of the $3^{\prime}$ end of SF and with ATG. In PCR 1B, the cDNA encoding the $\mathrm{rH}_{2} \mathrm{R}$ followed by a hexahistidine tag in $3^{\prime}$ position was generated. The hexahistidine tag was included to allow future purification and to provide additional protection against proteolysis (Seifert et al., 1998a). The sense primer consisted of $15 \mathrm{bp}$ of the $3^{\prime}$ end of SF and the first $22 \mathrm{bp}$ of the $5^{\prime}$ end of the $\mathrm{rH}_{2} \mathrm{R}$. The antisense primer consisted of $18 \mathrm{bp}$ of the $\mathrm{C}$ terminus of the $\mathrm{rH}_{2} \mathrm{R}$, the hexahistidine tag, the stop codon, and an XbaI site. The cDNA for the $\mathrm{rH}_{2} \mathrm{R}$ was extracted from pcDNA- $\mathrm{HH}_{2} \mathrm{R}$ after restriction digestion with HindIII and BglII and was used as template. In PCR 2, the products of PCR 1A and PCR 1B annealed in the region encoding SF and ATG. Here, the sense primer of PCR 1A and the antisense primer of PCR 1B were used. In that way, a fragment encoding SF, the $\mathrm{rH}_{2} \mathrm{R}$, the hexahistidine tag, the stop codon, and an XbaI site was 
obtained. This fragment was digested with SacI and XbaI and cloned into pGEM-3Z-SF-hH ${ }_{2} \mathrm{R}$ digested with SacI and XbaI to yield pGEM3Z-SF- $\mathrm{rH}_{2} \mathrm{R}$. pGEM-3Z-SF-rH ${ }_{2} \mathrm{R}$ was digested with SacI and XbaI and cloned into the baculovirus transfer vector $\mathrm{pVL} 1392-\mathrm{SF}-\mathrm{hH}_{2} \mathrm{R}$ digested with SacI and XbaI. With pGEM-3Z-SF- $\mathrm{rH}_{2} \mathrm{R}$ as template, the sense primer of PCR $1 \mathrm{~A}$, and an antisense primer encoding six histidines, in PCR 3A a fragment encoding SF, the cDNA for the $\mathrm{rH}_{2} \mathrm{R}$, and the hexahistidine tag was generated. In PCR 3B, a fragment encoding the hexahistidine tag, the cDNA of $\mathrm{G}_{\mathrm{s} \alpha \mathrm{S}}$, the stop codon, and an XbaI site was generated. Here, the sense primer annealed with the hexahistidine tag and the start codon of $\mathrm{G}_{\mathrm{s} \alpha \mathrm{S}}$, and the antisense primer annealed with the cDNA encoding the five C-terminal amino acids of $\mathrm{G}_{\mathrm{s} \alpha \mathrm{S}}$, the stop codon, and an XbaI site. pGEM-3Z-SF-gpH ${ }_{2} \mathrm{R}_{-} \mathrm{G}_{\mathrm{s} \alpha \mathrm{S}}$ was used as template. In PCR 4, the products of PCRs $3 \mathrm{~A}$ and $3 \mathrm{~B}$ annealed in the hexahistidine region, and the sense primer of PCR $1 \mathrm{~A}$ and the antisense primer of PCR 3B were used. In that way, the complete cDNA for the $\mathrm{rH}_{2} \mathrm{R}-\mathrm{G}_{\mathrm{s} \alpha \mathrm{S}}$ fusion protein, consisting of $\mathrm{SF}$, the cDNA for the $\mathrm{rH}_{2} \mathrm{R}$, the hexahistidine tag, and the cDNA of $\mathrm{G}_{\mathrm{s} \alpha \mathrm{S}}$ was amplified. The product of PCR 4 was digested with SacI and BglII and cloned into pGEM-3Z-SF- $\beta_{1}$ AR$\mathrm{G}_{\mathrm{s} \alpha \mathrm{S}}$ digested with SacI and BglII. In addition, the PCR 4 product was digested with SacI and BglII and directly cloned into pVL1392SF- $\beta_{1}$ AR- ${ }_{\text {Gs } \alpha \text { S }}$ that was digested with SacI and BglII and treated with calf intestinal phosphatase to yield the baculovirus transfer vector $\mathrm{pVL} 1392-\mathrm{SF}-\mathrm{rH}_{2} \mathrm{R}-\mathrm{G}_{\mathrm{s} \alpha \mathrm{S}}$.

Construction of the cDNAs for $\mathbf{c H}_{2} \mathbf{R}$ and $\mathbf{c H}_{2} \mathbf{R}-G_{\mathrm{s} \alpha \mathrm{S}}$. The strategy for the generation of the cDNAs for the epitope-tagged $\mathrm{cH}_{2} \mathrm{R}$ and $\mathrm{cH}_{2} \mathrm{R}-\mathrm{G}_{\mathrm{s} \alpha \mathrm{S}}$ was analogous to the strategy for the generation of the cDNAs for $\mathrm{rH}_{2} \mathrm{R}$ and $\mathrm{rH}_{2} \mathrm{R}-\mathrm{G}_{\mathrm{s} \alpha \mathrm{S}}$. With pGEM-3Z-SF-gpH $\mathrm{H}_{2} \mathrm{R}-\mathrm{G}_{\mathrm{s} \alpha \mathrm{S}}$ as template, in PCR 1A the SF region and the start codon of the $\mathrm{cH}_{2} \mathrm{R}$ were amplified. The sense primer annealed with $18 \mathrm{bp}$ of pGEM-3Z before the $5^{\prime}$ end of SF, and the antisense primer annealed with 15 bp of the $3^{\prime}$ end of SF and with ATG. In PCR 1B, the cDNA encoding the sequence for the $\mathrm{cH}_{2} \mathrm{R}$ followed by the hexahistidine tag in $3^{\prime}$ position was generated. The sense primer consisted of $15 \mathrm{bp}$ of the $3^{\prime}$ end of $\mathrm{SF}$ and the first $21 \mathrm{bp}$ of the $5^{\prime}$ end of $\mathrm{cH}_{2} \mathrm{R}$. The antisense primer consisted of $18 \mathrm{bp}$ of the $\mathrm{C}$ terminus of the $\mathrm{cH}_{2} \mathrm{R}$, the hexahistidine tag, the stop codon, and an $\mathrm{XbaI}$ site. The cDNA for the $\mathrm{cH}_{2} \mathrm{R}$ was extracted from CMVneo- $\mathrm{cH}_{2} \mathrm{R}$ after digestion with BglII and was used as template. In PCR 2, the products of PCR 1A and PCR 1B annealed in the region encoding SF and ATG. Here, the sense primer of PCR 1A and the antisense primer of PCR 1B were used. In that way, a fragment encoding $\mathrm{SF}$, the $\mathrm{cH}_{2} \mathrm{R}$, the hexahistidine tag, the stop codon, and an XbaI site was obtained. This fragment was digested with SacI and XbaI and cloned into pGEM$3 Z-S F-h H_{2} R$ digested with SacI and XbaI to yield pGEM-3Z-SF$\mathrm{cH}_{2}$ R. pGEM-3Z-SF-cH $\mathrm{C}_{2} \mathrm{R}$ was digested with SacI and $\mathrm{XbaI}$ and cloned into the baculovirus transfer vector $\mathrm{pVL} 1392-\mathrm{SF}-\mathrm{hH}_{2} \mathrm{R}$ digested with SacI and XbaI. PCR 3 was used to generate a fragment encoding the $\mathrm{C}$ terminus of the $\mathrm{cH}_{2} \mathrm{R}$, the hexahistidine tag, and $\mathrm{G}_{\mathrm{s} \alpha \mathrm{S}}$. The sense primer encoded the last 10 amino acids of the $\mathrm{C}$ terminus of the $\mathrm{cH}_{2} \mathrm{R}$, the hexahistidine tag, and the start codon of $\mathrm{G}_{\mathrm{s} \alpha \mathrm{S}}$, and the antisense primer encoded the five C-terminal amino acids of $G_{s \alpha S}$, the stop codon, and an XbaI site. Here, pGEM-3Z-SF$\mathrm{hH}_{2} \mathrm{R}-\mathrm{G}_{\mathrm{s} \alpha \mathrm{S}}$ was used as template. This fragment was digested with $\mathrm{XhoI}$ and $\mathrm{XbaI}$ and cloned into pGEM-3Z-SF-c $\mathrm{H}_{2} \mathrm{R}$ digested with XhoI and XbaI to yield pGEM-3Z-SF- $\mathrm{cH}_{2} \mathrm{R}-\mathrm{G}_{\mathrm{s} \alpha \mathrm{S}}$. pGEM-3Z-SF- $\mathrm{cH}_{2} \mathrm{R}$ Gs $\alpha$ S was digested with SacI and BglII and cloned into pVL1392SF- $\beta_{1} A R-G_{s \alpha S}$ that was digested with SacI and BglII and treated with calf intestinal phosphatase to yield the baculovirus transfer vector $\mathrm{pVL} 1392-\mathrm{SF}-\mathrm{cH}_{2} \mathrm{R}-\mathrm{G}_{\mathrm{s} \alpha \mathrm{S}}$.

Generation of Recombinant Baculoviruses, Cell Culture, and Membrane Preparation. Recombinant baculoviruses encoding $\mathrm{rH}_{2} \mathrm{R}, \mathrm{cH}_{2} \mathrm{R}, \mathrm{rH}_{2} \mathrm{R}-\mathrm{G}_{\mathrm{s} \alpha \mathrm{S}}$, and $\mathrm{cH}_{2} \mathrm{R}-\mathrm{G}_{\mathrm{s} \alpha \mathrm{S}}$ were generated in Sf9 cells using the BaculoGOLD transfection kit (BD Biosciences PharMingen, San Diego, CA) according to the manufacturer's instructions. After initial transfection, high-titer virus stocks were generated by two sequential virus amplifications. Sf9 cells were cultured in 250-ml disposable Erlenmeyer flasks at $28^{\circ} \mathrm{C}$ under rotation at $125 \mathrm{rpm}$ in SF 900 II medium (Invitrogen, Carlsbad, CA) supplemented with 5\% (v/v) fetal calf serum (Cambrex Bio Science Walkersville Inc., Walkersville, MD) and $0.1 \mathrm{mg} / \mathrm{ml}$ gentamicin (Cambrex Bio Science Walkersville Inc.). Cells were maintained at a density of 0.5 to $6.0 \times 10^{6}$ cells $/ \mathrm{ml}$. For infection, cells were sedimented by centrifugation and suspended in fresh medium. Cells were seeded at $3.0 \times 10^{6} \mathrm{cells} / \mathrm{ml}$ and infected with a 1:100 dilution of high-titer baculovirus stocks encoding $\mathrm{H}_{2} \mathrm{Rs}, \mathrm{G}_{\mathrm{s} \alpha \mathrm{S}}$, and $\mathrm{H}_{2} \mathrm{R}-\mathrm{G}_{\mathrm{s} \alpha \mathrm{S}}$ fusion proteins. Cells were cultured for $48 \mathrm{~h}$ before membrane preparation. Sf9 membranes were prepared as described previously (Seifert et al., 1998a), using $1 \mathrm{mM}$ EDTA, $0.2 \mathrm{mM}$ phenylmethylsulfonyl fluoride, $10 \mu \mathrm{g} / \mathrm{ml}$ benzamidine, and $10 \mu \mathrm{g} / \mathrm{ml}$ leupeptin as protease inhibitors. Membranes were suspended in binding buffer $\left(12.5 \mathrm{mM} \mathrm{MgCl}_{2}, 1 \mathrm{mM}\right.$ EDTA, and $75 \mathrm{mM}$ Tris-HCl, $\mathrm{pH} 7.4$ ) and stored at $-80^{\circ} \mathrm{C}$ until use.

SDS-PAGE and Immunoblot Analysis. Membrane proteins were separated on SDS polyacrylamide gels containing $12 \%(\mathrm{w} / \mathrm{v})$ acrylamide. Proteins were then transferred onto Immobilon-P transfer membranes (Millipore Corporation, Bedford, MA). Membranes were reacted with $\mathrm{M} 1$ antibody, anti- $\mathrm{G}_{\mathrm{s} \alpha} \mathrm{Ig}$, or anti-His ${ }_{6}$ Ig (1:1000 each). Immunoreactive bands were visualized by enhanced chemoluminescence (Pierce Chemical, Rockford, IL) using sheep anti-mouse IgG (M1 and anti-His ${ }_{6}$ Ig) and donkey anti-rabbit IgG (anti-G s $\alpha_{\text {Ig) }}$, respectively, coupled to peroxidase.

Steady-State GTPase Activity Assay. Membranes were thawed, sedimented, and resuspended in $10 \mathrm{mM}$ Tris- $\mathrm{HCl}, \mathrm{pH}$ 7.4. Assay tubes contained Sf9 membranes expressing $\mathrm{H}_{2} \mathrm{R}-\mathrm{G}_{\mathrm{s} \alpha \mathrm{S}}$ fusion proteins (10 $\mu \mathrm{g}$ of protein/tube), $1.0 \mathrm{mM} \mathrm{MgCl}_{2}, 0.1 \mathrm{mM}$ EDTA, 0.1 mM ATP, $100 \mathrm{nM}$ GTP, $0.1 \mathrm{mM}$ adenylyl imidodiphosphate, $5 \mathrm{mM}$ creatine phosphate, $40 \mu \mathrm{g}$ of creatine kinase, and $0.2 \%(\mathrm{w} / \mathrm{v})$ bovine serum albumin in $50 \mathrm{mM}$ Tris- $\mathrm{HCl}, \mathrm{pH} 7.4$, and $\mathrm{H}_{2} \mathrm{R}$ ligands at various concentrations. Reaction mixtures $(80 \mu \mathrm{l})$ were incubated for $2 \mathrm{~min}$ at $25^{\circ} \mathrm{C}$ before the addition of $20 \mu \mathrm{l}$ of $\left[\gamma^{32} \mathrm{P}\right] \mathrm{GTP}(0.1 \mu \mathrm{Ci} /$ tube). All stock and work dilutions of $\left[\gamma^{-32} \mathrm{P}\right]$ GTP were prepared in 20 $\mathrm{mM}$ Tris-HCl, $\mathrm{pH}$ 7.4. Reactions were conducted for $20 \mathrm{~min}$ at $25^{\circ} \mathrm{C}$. Preliminary studies under basal conditions and with HA, IMP, and ARP showed that under these conditions, GTP hydrolysis was linear. Reactions were terminated by the addition of $900 \mu \mathrm{l}$ of slurry consisting of $5 \%$ (w/v) activated charcoal and $50 \mathrm{mM} \mathrm{NaH}_{2} \mathrm{PO}_{4}, \mathrm{pH} 2.0$. Charcoal absorbs nucleotides but not $\mathrm{P}_{\mathrm{i}}$. Charcoal-quenched reaction mixtures were centrifuged for $7 \mathrm{~min}$ at room temperature at $15,000 \mathrm{~g}$. Six hundred microliters of the supernatant fluid of reaction mixtures was removed, and ${ }^{32} \mathrm{P}_{\mathrm{i}}$ was determined by liquid scintillation counting. Enzyme activities were corrected for spontaneous degradation of $\left[\gamma^{-}{ }^{32} \mathrm{P}\right]$ GTP. Spontaneous $\left[\gamma_{-}{ }^{32} \mathrm{P}\right]$ GTP degradation was determined in tubes containing all of the above-described components plus a very high concentration of unlabeled GTP $(1 \mathrm{mM})$ that, by competition with $\left[\gamma_{-}{ }^{32} \mathrm{P}\right] \mathrm{GTP}$, prevents $\left[\gamma_{-}{ }^{32} \mathrm{P}\right] \mathrm{GTP}$ hydrolysis by enzymatic activities present in Sf9 membranes. Spontaneous $\left[\gamma_{-}{ }^{32} \mathrm{P}\right] \mathrm{GTP}$ degradation was $<1 \%$ of the total amount of radioactivity added using 20 $\mathrm{mM}$ Tris-HCl, $\mathrm{pH} 7.4$, as solvent for $\left[\gamma-{ }^{32} \mathrm{P}\right] \mathrm{GTP}$. The experimental conditions chosen ensured that not more than $10 \%$ of the total amount of $\left[\gamma_{-}{ }^{32} \mathrm{P}\right]$ GTP added was converted to ${ }^{32} \mathrm{P}_{\mathrm{i}}$.

AC Activity Assay. AC activity in Sf9 membranes was determined as described previously (Houston et al., 2002). In brief, membranes were thawed and sedimented by a 15 -min centrifugation at $4^{\circ} \mathrm{C}$ and $15,000 \mathrm{~g}$ to remove residual endogenous guanine nucleotides as far as possible, and they were subsequently resuspended in binding buffer. Tubes contained Sf9 membranes expressing $\mathrm{H}_{2} \mathrm{Rs}(100 \mu \mathrm{g}$ of protein/tube), $\mathrm{H}_{2} \mathrm{Rs}$ coexpressed with mammalian $\mathrm{G}_{\mathrm{s} \alpha \mathrm{S}}(50 \mu \mathrm{g}$ of protein/tube), or $\mathrm{H}_{2} \mathrm{R}-\mathrm{G}_{\mathrm{s} \alpha \mathrm{S}}$ fusion proteins (20 $\mu \mathrm{g}$ of protein/tube), additionally $5 \mathrm{mM} \mathrm{MgCl}_{2}, 0.4 \mathrm{mM}$ EDTA, and $30 \mathrm{mM}$ Tris-HCl, $\mathrm{pH}$ 7.4. Assay tubes containing membranes and various additions in a total volume of $30 \mu \mathrm{l}$ were incubated for $3 \mathrm{~min}$ at $37^{\circ} \mathrm{C}$ before starting reactions by the addition of $20 \mu \mathrm{l}$ of reaction mixture containing (final) $\left[\alpha_{-}{ }^{32} \mathrm{P}\right] \mathrm{ATP}(0.3 \mu \mathrm{Ci} /$ tube $)$ plus $40 \mu \mathrm{M}$ unlabeled ATP, $2.7 \mathrm{mM}$ mono(cyclohexyl)ammonium phosphoenolpyruvate, 0.125 IU of pyruvate kinase, $1 \mathrm{IU}$ of myokinase, and $0.1 \mathrm{mM}$ cAMP. Reactions were 
conducted for $20 \mathrm{~min}$ at $37^{\circ} \mathrm{C}$. Reactions were terminated by the addition of $20 \mu \mathrm{l}$ of $2.2 \mathrm{~N} \mathrm{HCl}$. Denatured protein was sedimented by a 3-min centrifugation at $25^{\circ} \mathrm{C}$ and $15,000 \mathrm{~g}$. Sixty-five microliters of the supernatant fluid was applied onto disposable columns filled with $1.3 \mathrm{~g}$ of neutral alumina (Sigma A-1522, super I, WN-6). $\left[{ }^{32} \mathrm{P}\right] \mathrm{cAMP}$ was separated from $\left[\alpha_{-}{ }^{32} \mathrm{P}\right]$ ATP by elution of $\left[{ }^{32} \mathrm{P}\right] \mathrm{cAMP}$ with $4 \mathrm{ml}$ of $0.1 \mathrm{M}$ ammonium acetate, $\mathrm{pH}$ 7.0. Recovery of $\left[{ }^{32} \mathrm{P}\right] \mathrm{cAMP}$ was $\sim 80 \%$. Blank values were routinely $\sim 0.01 \%$ of the total amount of $\left[\alpha^{-32} \mathrm{P}\right] \mathrm{ATP}$ added. $\left[{ }^{32} \mathrm{P}\right] \mathrm{cAMP}$ was determined by liquid scintillation counting. The experimental conditions chosen ensured that not more than 1 to $3 \%$ of the total amount of $\left[\alpha-{ }^{32} \mathrm{P}\right] \mathrm{ATP}$ added was converted to $\left[{ }^{32} \mathrm{P}\right] \mathrm{cAMP}$.

Miscellaneous. Protein concentrations were determined using the DC protein assay kit (Bio-Rad, Hercules, CA). $\left[{ }^{3} \mathrm{H}\right]$ Dihydroalprenolol saturation binding was performed as described previously (Seifert et al., 1998a). All analyses of experimental data were performed with the Prism 4 program (GraphPad Software Inc., San Diego, CA). $K_{\mathrm{B}}$ values were calculated using the Cheng and Prusoff equation (1973) equation. Expression levels of recombinant proteins were determined using the Bio-Rad GS-710 calibrated imaging densitometer and the software tool Quantity One, version 4.0.3 (Bio-Rad).

\section{Results}

Immunological Detection of Recombinant Proteins in Sf9 Cell Membranes. The predicted molecular mass of the $\mathrm{H}_{2} \mathrm{R}$ is $\sim 33 \mathrm{kDa}$ (Gantz et al., 1991a,b; Fukushima et al., 1997). $\mathrm{H}_{2} \mathrm{R}$ species isoforms presumably exhibit similar glycosylation patterns, because the putative $N$-glycosylation sites for the $\mathrm{H}_{2} \mathrm{R}$, Asn-4, and Asn-162 are fully conserved within their sequences (Fig. 1) (Fukushima et al., 1995). However, only $\mathrm{rH}_{2} \mathrm{R}$ and $\mathrm{hH}_{2} \mathrm{R}$ migrated as the expected bands for monomeric GPCRs (Fig. 3, A and B). Both bands occur as doublets, representing different glycosylation forms (Houston et al., 2002). Additional bands were detected at $\sim 70$
$\mathrm{kDa}$, presumably representing receptor dimers. A similar pattern of immunoreactive bands was previously observed for the $\mathrm{hH}_{2} \mathrm{R}$ (Houston et al., 2002). In contrast, both $\mathrm{cH}_{2} \mathrm{R}$ and $\mathrm{gpH}_{2} \mathrm{R}$ displayed strong doublet bands at $\sim 60 \mathrm{kDa}$ that coincide with the expected bands of differentially glycosylated $\mathrm{H}_{2} \mathrm{R}$ dimers, whereas the bands for monomers were absent. Additional bands were detected at $\sim 150 \mathrm{kDa}$ and above $250 \mathrm{kDa}$, possibly corresponding to $\mathrm{H}_{2} \mathrm{R}$ tetramers and higher oligomers, respectively. Dimerization and oligomerization of the $\mathrm{cH}_{2} \mathrm{R}$ has been described previously (Fukushima et al., 1997), but in those experiments, also receptor monomers were detected. Hence, $\mathrm{gpH}_{2} \mathrm{R}$ and $\mathrm{cH}_{2} \mathrm{R}$ possibly migrated atypically in SDS-PAGE, i.e., the bands at $\sim 60$ and $\sim 150 \mathrm{kDa}$ could correspond to monomers and dimers, respectively, and not to dimers and tetramers. With the anti-His ${ }_{6}$ Ig, in membranes expressing $\mathrm{cH}_{2} \mathrm{R}$, an additional doublet band at $\sim 23 \mathrm{kDa}$ was detected, and in $\mathrm{rH}_{2} \mathrm{R}$ - and $\mathrm{hH}_{2} \mathrm{R}$ membranes, an $\sim 27-\mathrm{kDa}$ band was present. However, no such bands were detected in $\mathrm{gpH}_{2} \mathrm{R}$ membranes. The $\sim 23-$ $27-\mathrm{kDa}$ bands may represent differentially and atypically migrating $\mathrm{H}_{2} \mathrm{R}$ monomers not recognized by the $\mathrm{M} 1$ antibody because of a lack of epitope exposure. By analogy to formyl peptide receptors (Wenzel-Seifert and Seifert, 2003) differences in the $\mathrm{C}$ termini of $\mathrm{H}_{2} \mathrm{R}$ species isoforms may constitute the molecular basis for the species-selective migration pattern. Thus, $\mathrm{H}_{2} \mathrm{R}$ species isoforms are well expressed in $\mathrm{Sf9}$ membranes, but due to their widely different migration, it is impossible to precisely assess their expression levels using $\beta_{2} \mathrm{AR}$-membranes calibrated with $\left[{ }^{3} \mathrm{H}\right]$ dihydroalprenolol saturation binding as standard (Kelley et al., 2001).

$\mathrm{H}_{2} \mathrm{R}-\mathrm{G}_{\mathrm{s} \alpha \mathrm{S}}$ fusion proteins of canine, rat, guinea pig, and human occurred as strong bands at $\sim 80 \mathrm{kDa}$ (Fig. 3C). Because $G_{\mathrm{s} \alpha \mathrm{S}}$ has an apparent molecular mass of $\sim 45 \mathrm{kDa}$, these bands correspond to $\mathrm{H}_{2} \mathrm{R}-\mathrm{G}_{\mathrm{s} \alpha \mathrm{S}}$ monomers. Weaker
A



C

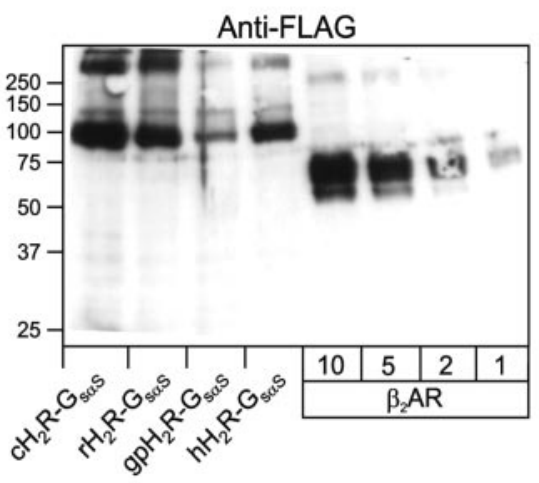

B

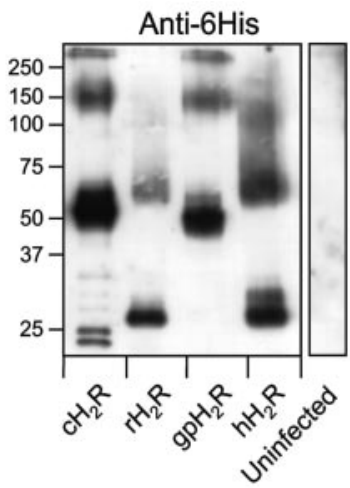

D

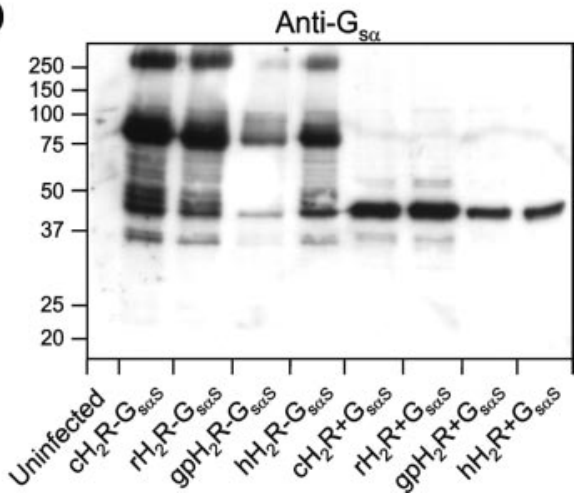

Fig. 3. Immunological detection and analysis of the expression of recombinant proteins in Sf9 cells. Sf9 membranes expressing various proteins were prepared, separated by SDSPAGE on gels containing $12 \%(\mathrm{w} / \mathrm{v})$ acrylamide, transferred onto Immobilon-P membranes, and probed with the respective Ig indicated on top of each panel. In each lane, $10 \mu \mathrm{g}$ of membrane protein was loaded onto the gel, unless otherwise indicated below membranes. Exceptionally, $40 \mu \mathrm{g}$ of a membrane expressing $\mathrm{gpH}_{2} \mathrm{R}$ $\mathrm{G}_{\mathrm{s} \alpha \mathrm{S}}$ were loaded onto the gels in $\mathrm{C}$ and D. Numbers on the left of membranes designate masses of marker proteins in kilodaltons. In A and C, 1 , 2,5 , and $10 \mu \mathrm{g}$ of protein of Sf9 membranes expressing the $\beta_{2} \mathrm{AR}$ at $7.5 \mathrm{pmol} \mathrm{mg}^{-1}$ (as determined by $\left[{ }^{3} \mathrm{H}\right]$ DHA saturation binding) were used as standard to assess the expression levels of $\mathrm{H}_{2} \mathrm{R}$ species isoforms. In $\mathrm{D}$, membranes expressing $\mathrm{H}_{2} \mathrm{R}-\mathrm{G}_{\mathrm{s} \alpha \mathrm{S}}$ fusion proteins and membranes coexpressing $\mathrm{H}_{2} \mathrm{R}$ species and mammalian $\mathrm{G}_{\mathrm{s} \alpha \mathrm{S}}$ were loaded onto the gel. 
bands were detected at $\sim 110 \mathrm{kDa}$, most probably representing differently glycosylated fusion proteins. With all species, additional bands at $\sim 250 \mathrm{kDa}$ were detected, presumably representing $\mathrm{H}_{2} \mathrm{R}-\mathrm{G}_{\mathrm{s} \alpha \mathrm{S}}$ dimers or oligomers. $\mathrm{cH}_{2} \mathrm{R}-\mathrm{G}_{\mathrm{s} \alpha \mathrm{S}}$ was

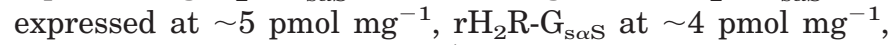
$\mathrm{gpH}_{2} \mathrm{R}-\mathrm{G}_{\mathrm{s} \alpha \mathrm{S}}$ at $\sim 1 \mathrm{pmol} \mathrm{mg}{ }^{-1}$, and $\mathrm{hH}_{2} \mathrm{R}-\mathrm{G}_{\mathrm{s} \alpha \mathrm{S}}$ at $\sim 3 \mathrm{pmol}$ $\mathrm{mg}^{-1}$ using $\beta_{2} \mathrm{AR}$-membranes as standard. To account for the decreased expression level of $\mathrm{gpH}_{2} \mathrm{R}-\mathrm{G}_{\mathrm{s} \alpha \mathrm{S}}$, in this case the amount of protein applied to the gel was adjusted to $40 \mu \mathrm{g}$.

Probing membranes expressing $\mathrm{H}_{2} \mathrm{R}-\mathrm{G}_{\mathrm{s} \alpha \mathrm{S}}$ species with the anti-G $\mathrm{G}_{\mathrm{s} \alpha}$ Ig yielded $\sim 80-$ and $\sim 250-\mathrm{kDa}$ bands (Fig. 3D), which are consistent with those bands observed with the anti-FLAG Ig. Additional bands occurred at $\sim 45 \mathrm{kDa}$, representing atypically migrating or partially degraded fusion proteins. In all membranes coexpressing $\mathrm{H}_{2} \mathrm{R}$ species and $\mathrm{G}_{\mathrm{s} \alpha \mathrm{S}}$, the expected bands for $G_{\mathrm{s} \alpha \mathrm{S}}$ monomers were detected at $\sim 45$ $\mathrm{kDa}$. The expression levels of $\mathrm{G}_{\mathrm{s} \alpha \mathrm{S}}$ in membranes coexpressing $\mathrm{H}_{2} \mathrm{R}$ and $\mathrm{G}_{\mathrm{s} \alpha \mathrm{S}}$ were estimated using the $\sim 80$-kDa peak intensities of $\mathrm{H}_{2} \mathrm{R}-\mathrm{G}_{\mathrm{s} \alpha \mathrm{S}}$ species as standard and were $\sim 2$ pmol $\mathrm{mg}^{-1}$ in membranes coexpressing $\mathrm{cH}_{2} \mathrm{R}$ and $\mathrm{G}_{\mathrm{s} \alpha \mathrm{S}}, \sim 2$ pmol $\mathrm{mg}^{-1}$ in membranes coexpressing $\mathrm{rH}_{2} \mathrm{R}$ and $\mathrm{G}_{\mathrm{s} \alpha \mathrm{S}}, \sim 1$ pmol mg ${ }^{-1}$ in membranes coexpressing $\mathrm{gpH}_{2} \mathrm{R}$ and $\mathrm{G}_{\mathrm{s} \alpha \mathrm{S}}$, and $\sim 1 \mathrm{pmol} \mathrm{mg}^{-1}$ in membranes coexpressing $\mathrm{hH}_{2} \mathrm{R}$ and $\mathrm{G}_{\mathrm{s} \alpha \mathrm{S}}$.

Efficacies and Potencies of Agonists at $\mathrm{H}_{2} \mathbf{R}-\mathrm{G}_{\mathrm{s} \alpha \mathrm{S}}$ Species Isoforms Derived from the GTPase Assay. Efficacies and potencies of compounds 1 to 22 at $H_{2} R-G_{s \alpha S}$ fusion proteins of human, guinea pig, rat, and canine are summarized in Table 1 . The small $\mathrm{H}_{2} \mathrm{R}$ agonists acted as full (1-3) or as nearly full (4) agonists at the four receptors with approximately similar efficacies. HA (1) and DIM (2) were equipotent at human, guinea pig, and rat $\mathrm{H}_{2} \mathrm{R}-\mathrm{G}_{\mathrm{s} \alpha \mathrm{S}}$, they but showed lower $\mathrm{EC}_{50}$ values at $\mathrm{cH}_{2} \mathrm{R}-\mathrm{G}_{\mathrm{s} \alpha \mathrm{S}}$. AMT (3) was slightly more potent at $\mathrm{cH}_{2} \mathrm{R}-\mathrm{G}_{\mathrm{s} \alpha \mathrm{S}}$ than at $\mathrm{hH}_{2} \mathrm{R}-\mathrm{G}_{\mathrm{s} \alpha \mathrm{S}}$ and $\mathrm{gpH}_{2} \mathrm{R}-\mathrm{G}_{\mathrm{s} \alpha \mathrm{S}}$. At $\mathrm{rH}_{2} \mathrm{R}-\mathrm{G}_{\mathrm{s} \alpha \mathrm{S}}$, the potency of AMT (3) was further decreased. BET (4) acted with increased potencies at $\mathrm{gpH}_{2} \mathrm{R}-\mathrm{G}_{\mathrm{s} \alpha \mathrm{S}}$ and $\mathrm{cH}_{2} \mathrm{R}-\mathrm{G}_{\mathrm{s} \alpha \mathrm{S}}$, compared with $\mathrm{hH}_{2} \mathrm{R}-\mathrm{G}_{\mathrm{s} \alpha \mathrm{S}}$ and $\mathrm{rH}_{2} \mathrm{R}-\mathrm{G}_{\mathrm{s} \alpha \mathrm{S}}$. In agreement with previous studies (Kelley et al., 2001; Xie et al., 2006a,b), $N$-[3-(1H-imidazol-4-yl)propyl]guanidines (8-10) and their $N^{\mathrm{G}}$-acylated analogs (11-16) were more potent and more efficacious at $\mathrm{gpH}_{2} \mathrm{R}-\mathrm{G}_{\mathrm{s} \alpha \mathrm{S}}$ than at $\mathrm{hH}_{2} \mathrm{R}_{-} \mathrm{G}_{\mathrm{s} \alpha \mathrm{S}}$ (Table 1). At $\mathrm{gpH}_{2} \mathrm{R}-\mathrm{G}_{\mathrm{s} \alpha \mathrm{S}}$, UR-PG222A (13) was more efficacious than $\mathrm{HA}(\mathbf{1})$. At $\mathrm{hH}_{2} \mathrm{R}-\mathrm{G}_{\mathrm{s} \alpha \mathrm{S}}$ and $\mathrm{rH}_{2} \mathrm{R}-\mathrm{G}_{\mathrm{s} \alpha \mathrm{S}}$, the compounds exhibited similar efficacies and potencies. Only UR-PG214 (11) was slightly more potent at $\mathrm{rH}_{2} \mathrm{R}-\mathrm{G}_{\mathrm{s} \alpha \mathrm{S}}$ than at $\mathrm{hH}_{2} \mathrm{R}-\mathrm{G}_{\mathrm{s} \alpha \mathrm{S}}$. Apart from $\mathrm{ARP}(\mathbf{9})$ and its $N^{\mathrm{G}}$-acylated analog UR-PG136 (15) that acted with similar efficacies at $\mathrm{cH}_{2} \mathrm{R}-\mathrm{G}_{\mathrm{s} \alpha \mathrm{S}}$ and $\mathrm{hH} \mathrm{H}_{2} \mathrm{R}-\mathrm{G}_{\mathrm{s} \alpha \mathrm{S}}$, compounds $\mathbf{8}$ to $\mathbf{1 6}$ were more efficacious at $\mathrm{cH}_{2} \mathrm{R}-\mathrm{G}_{\mathrm{s} \alpha \mathrm{S}}$ than at $\mathrm{hH}_{2} \mathrm{R}-\mathrm{G}_{\mathrm{s} \alpha \mathrm{S}}$. Compounds 8 to 16 were also more potent at $\mathrm{cH}_{2} \mathrm{R}-\mathrm{G}_{\mathrm{s} \alpha \mathrm{S}}$ than at $\mathrm{hH}_{2} \mathrm{R}-\mathrm{G}_{\mathrm{s} \alpha \mathrm{S}}$. An exception of this rule was UR-PG123 (14) that exhibited the largest efficacy increase $(\sim 4$-fold) but was somewhat less potent at $\mathrm{cH}_{2} \mathrm{R}-\mathrm{G}_{\mathrm{s} \alpha \mathrm{S}}$ than at $\mathrm{hH}_{2} \mathrm{R}-\mathrm{G}_{\mathrm{s} \alpha \mathrm{S}}$. In summary, small $\mathrm{H}_{2} \mathrm{R}$ agonists 1 to 4 acted with similar efficacies at all $\mathrm{H}_{2} \mathrm{R}$ $\mathrm{G}_{\mathrm{s} \alpha \mathrm{S}}$ species isoforms investigated, but they were more potent at $\mathrm{cH}_{2} \mathrm{R}-\mathrm{G}_{\mathrm{s} \alpha \mathrm{S}}$ compared with $\mathrm{hH}_{2} \mathrm{R}-\mathrm{G}_{\mathrm{s} \alpha \mathrm{S}}, \mathrm{gpH}_{2} \mathrm{R}-\mathrm{G}_{\mathrm{s} \alpha \mathrm{S}}$, and $\mathrm{rH}_{2} \mathrm{R}-\mathrm{G}_{\mathrm{s} \alpha \mathrm{S}}$. Guanidines and $N^{\mathrm{G}}$-acylated guanidines 8 to 16 acted with increased efficacies and potencies at $\mathrm{gpH}_{2} \mathrm{R}$ $\mathrm{G}_{\mathrm{s} \alpha \mathrm{S}}$ and $\mathrm{cH}_{2} \mathrm{R}-\mathrm{G}_{\mathrm{s} \alpha \mathrm{S}}$ compared with $\mathrm{hH}_{2} \mathrm{R}-\mathrm{G}_{\mathrm{s} \alpha \mathrm{S}}$, whereas no selectivity was observed between $\mathrm{rH}_{2} \mathrm{R}-\mathrm{G}_{\mathrm{s} \alpha \mathrm{S}}$ and $\mathrm{hH}_{2} \mathrm{R}-\mathrm{G}_{\mathrm{s} \alpha \mathrm{S}}$.

Compounds 5 and $\mathbf{6}$ are representatives of $\mathrm{H}_{1} \mathrm{R}$ agonists with partial $\mathrm{H}_{2} \mathrm{R}$ agonism (Seifert et al., 2003). Both compounds were less efficacious at $\mathrm{gpH}_{2} \mathrm{R}-\mathrm{G}_{\mathrm{s} \alpha \mathrm{S}}$ than at $\mathrm{hH}_{2} \mathrm{R}$ -
$\mathrm{G}_{\mathrm{s} \alpha \mathrm{S}}$ and similarly efficacious at $\mathrm{rH}_{2} \mathrm{R}-\mathrm{G}_{\mathrm{s} \alpha \mathrm{S}}$ and $\mathrm{hH}_{2} \mathrm{R}-\mathrm{G}_{\mathrm{s} \alpha \mathrm{S}}$ (Table 1). In the GTPase assay at $\mathrm{H}_{2} \mathrm{R}-\mathrm{G}_{\mathrm{s} \alpha \mathrm{S}}$ fusion proteins, burimamide (7) was a weak partial agonist with similar efficacies at human, guinea pig, and rat species. Strikingly, compounds 5, 6, and $\mathbf{7}$ acted with significantly increased efficacies at $\mathrm{cH}_{2} \mathrm{R}-\mathrm{G}_{\mathrm{s} \alpha \mathrm{S}}$ compared with $\mathrm{hH}_{2} \mathrm{R}-\mathrm{G}_{\mathrm{s} \alpha \mathrm{S}}$. Apart from 2-benzylhistamine (5) with $\sim 2$-fold increased potency at $\mathrm{gpH}_{2} \mathrm{R}-\mathrm{G}_{\mathrm{s} \alpha \mathrm{S}}$, the potencies of $\mathbf{5}$ to $\mathbf{7}$ did not significantly differ between the species investigated. Taken together, partial $\mathrm{H}_{2} \mathrm{R}$ agonists were considerably more efficacious at $\mathrm{cH}_{2} \mathrm{R}$ $\mathrm{G}_{\mathrm{s} \alpha \mathrm{S}}$ than at human, guinea pig, and rat $\mathrm{H}_{2} \mathrm{R}-\mathrm{G}_{\mathrm{s} \alpha \mathrm{S}}$.

Potencies and Inverse Agonist Efficacies of Antagonists at $H_{2} R-G_{s \alpha S}$ Species Isoforms Derived from the GTPase Assay. $K_{\mathrm{B}}$ values and inverse agonist efficacies of the $\mathrm{H}_{2} \mathrm{R}$ antagonists CIM (17), RAN (18), FAM (19), APT (20), and IAPT (21) are listed in Table 2. The compounds decreased GTPase activities below basal values and thus acted as inverse agonists at all four species. At $h H_{2} R-G_{s \alpha S}$ and $\mathrm{gpH}_{2} \mathrm{R}-\mathrm{G}_{\mathrm{s} \alpha \mathrm{S}}$ compounds $\mathbf{1 7}$ to $\mathbf{2 1}$ decreased the basal GTPase signal $(0 \%)$ by $\sim 10 \%$ if the maximal stimulatory effect of $100 \mu \mathrm{M} H A$ was set to $100 \%$. At $\mathrm{rH}_{2} \mathrm{R}-\mathrm{G}_{\mathrm{s} \alpha \mathrm{S}}$ the inverse agonist efficacies of $\mathbf{1 7}$ to $\mathbf{2 1}$ were somewhat smaller. At $\mathrm{cH}_{2} \mathrm{R}-\mathrm{G}_{\mathrm{s} \alpha \mathrm{S}}$ all compounds except CIM (17) showed a significantly higher reduction of the basal GTPase activity by $\sim 20 \%$. The $K_{\mathrm{B}}$ values of $\mathbf{1 7}$ to $\mathbf{2 1}$ were similar at $\mathrm{hH}_{2} \mathrm{R}-\mathrm{G}_{\mathrm{s} \alpha \mathrm{S}}$ and $\mathrm{gpH}_{2} \mathrm{R}-\mathrm{G}_{\mathrm{s} \alpha \mathrm{S}}$. At $\mathrm{rH}_{2} \mathrm{R}-\mathrm{G}_{\mathrm{s} \alpha \mathrm{S}}, \mathbf{1 7}$ to $\mathbf{1 9}$ were less potent, and 20 and 21 were similarly potent compared with $\mathrm{hH}_{2} \mathrm{R}$ $\mathrm{G}_{\mathrm{s} \alpha \mathrm{S}}$. By contrast, all compounds except FAM (19) were less potent at $\mathrm{cH}_{2} \mathrm{R}-\mathrm{G}_{\mathrm{s} \alpha \mathrm{S}}$ than at $h \mathrm{H}_{2} \mathrm{R}-\mathrm{G}_{\mathrm{s} \alpha \mathrm{S}}$. Taken together, most of the $\mathrm{H}_{2} \mathrm{R}$ antagonists studied displayed increased inverse agonist efficacies and decreased potencies at $\mathrm{cH}_{2} \mathrm{R}$ $\mathrm{G}_{\mathrm{s} \alpha \mathrm{S}}$ compared with $\mathrm{hH}_{2} \mathrm{R}-\mathrm{G}_{\mathrm{s} \alpha \mathrm{S}}$.

Constitutive Activities of $h_{2} R-G_{s \alpha S}, g_{2} H_{2} R-G_{s \alpha S}$, $\mathbf{r H}_{2} \mathbf{R}-\mathbf{G}_{\mathbf{s} \alpha \mathrm{S}}$, and $\mathbf{c H}_{2} \mathbf{R}-\mathrm{G}_{\mathrm{s} \alpha \mathrm{S}}$ in the GTPase Assay. As was reported for a constitutively activated mutant of the $\beta_{2} \mathrm{AR}$ (Samama et al., 1993), the following major hallmarks distinguish constitutively active GPCRs from not (quiescent) or less constitutively active GPCRs. First, the efficacies of partial agonists are increased at the more constitutively active receptor. To uncover differences in the constitutive activities among $\mathrm{H}_{2} \mathrm{R}-\mathrm{G}_{\mathrm{s} \alpha \mathrm{S}}$ species, efficacies of partial and full agonists 1 to 16 and inverse agonist efficacies of antagonists 17 to 21 were compared at $\mathrm{hH}_{2} \mathrm{R}-\mathrm{G}_{\mathrm{s} \alpha \mathrm{S}}$ with $\mathrm{gpH}_{2} \mathrm{R}-\mathrm{G}_{\mathrm{s} \alpha \mathrm{S}}, \mathrm{rH}_{2} \mathrm{R}$ $\mathrm{G}_{\mathrm{s} \alpha \mathrm{S}}$, and $\mathrm{cH}_{2} \mathrm{R}-\mathrm{G}_{\mathrm{s} \alpha \mathrm{S}}$, respectively (Fig. 4, A, C, and E). Second, constitutively active receptors exhibit an increased affinity for agonists but not antagonists, with the extent of affinity increase being correlated with the efficacy of the ligand (Lefkowitz et al., 1993). Essentially, the potencies in the GTPase assay represent apparent affinities and can be therefore related, as $\log \mathrm{EC}_{50}$ differences between $\mathrm{hH}_{2} \mathrm{R}-\mathrm{G}_{\mathrm{s} \alpha \mathrm{S}}$ and the other $\mathrm{H}_{2} \mathrm{R}$ species isoforms, to the corresponding efficacies at $\mathrm{hH}_{2} \mathrm{R}-\mathrm{G}_{\mathrm{s} \alpha \mathrm{S}}$ (Fig. 4, B, D, and F). Finally, at receptors with increased constitutive activity inverse agonists have an elevated inhibitory effect on GTP hydrolysis (Seifert et al., 1998b).

Similar inverse agonist efficacies of antagonists $\mathbf{1 7}$ to $\mathbf{2 1}$ and the absence of selectivity in the efficacies of partial agonists 5 to $\mathbf{7}$ and $\mathbf{1 4}$ indicate equal magnitudes of constitutive activities for $\mathrm{gpH}_{2} \mathrm{R}-\mathrm{G}_{\mathrm{s} \alpha \mathrm{S}}$ and $\mathrm{hH}_{2} \mathrm{R}-\mathrm{G}_{\mathrm{s} \alpha \mathrm{S}}$ (Fig. 4A). As Fig. 4B illustrates, a poor but significant correlation $\left(r^{2}=\right.$ $0.27 ; p=0.016$ ) was observed between the $\log$ (potency ratio) of these species and the efficacies of compounds $\mathbf{1}$ to $\mathbf{2 1}$ at 





TABLE 2

Potencies and inverse agonist efficacies of antagonists at $\mathrm{H}_{2} \mathrm{R}-\mathrm{G}_{\mathrm{s} \alpha \mathrm{S}}$ species isoforms in the GTPase assay

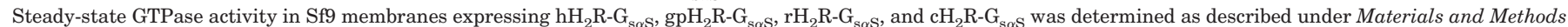

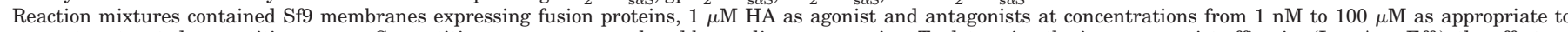





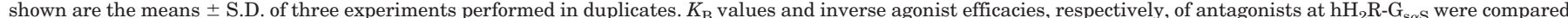

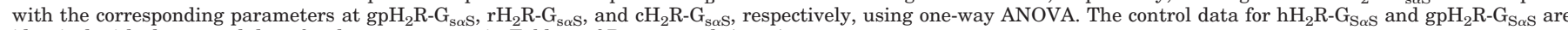
identical with the control data for these constructs in Table 2 of Preuss et al. (2007).

\begin{tabular}{|c|c|c|c|c|c|c|c|c|c|}
\hline & \multirow{2}{*}{ Compound } & \multicolumn{2}{|c|}{$\mathrm{hH}_{2} \mathrm{R}-\mathrm{G}_{\mathrm{s} \alpha \mathrm{S}}$} & \multicolumn{2}{|c|}{$\mathrm{gpH}_{2} \mathrm{R}-\mathrm{G}_{\mathrm{s} \alpha \mathrm{S}}$} & \multicolumn{2}{|c|}{$\mathrm{rH}_{2} \mathrm{R}-\mathrm{G}_{\mathrm{s} \alpha \mathrm{S}}$} & \multicolumn{2}{|c|}{$\mathrm{cH}_{2} \mathrm{R}-\mathrm{G}_{\mathrm{s} \alpha \mathrm{S}}$} \\
\hline & & $K_{\mathrm{B}}$ & Inv. Ago. Eff. & $K_{\mathrm{B}}{ }^{a}$ & Inv. Ago. Eff. & $K_{\mathrm{B}}{ }^{a}$ & Inv. Ago. Eff. ${ }^{b}$ & $K_{\mathrm{B}}$ & Inv. Ago. Eff. ${ }^{b}$ \\
\hline & & $n M$ & & $n M$ & & $n M$ & & $n M$ & \\
\hline 17 & CIM & $1700 \pm 430$ & $-0.08 \pm 0.01$ & $1300 \pm 270$ & $-0.09 \pm 0.02$ & $2800 \pm 340^{*}$ & $-0.06 \pm 0.01$ & $7500 \pm 400 * *$ & $-0.07 \pm 0.02$ \\
\hline 18 & RAN & $840 \pm 94$ & $-0.09 \pm 0.01$ & $1000 \pm 170$ & $-0.08 \pm 0.01$ & $2100 \pm 410^{* *}$ & $-0.06 \pm 0.01^{++}$ & $1500 \pm 160^{*}$ & $-0.18 \pm 0.01^{++}$ \\
\hline 19 & FAM & $48 \pm 10$ & $-0.10 \pm 0.02$ & $38 \pm 3$ & $-0.10 \pm 0.01$ & $91 \pm 7 * *$ & $-0.07 \pm 0.01^{+}$ & $59 \pm 1$ & $-0.22 \pm 0.01^{++}$ \\
\hline 20 & APT & $180 \pm 12$ & $-0.09 \pm 0.01$ & $260 \pm 43^{*}$ & $-0.09 \pm 0.01$ & $170 \pm 27$ & $-0.06 \pm 0.01^{+}$ & $620 \pm 49^{* *}$ & $-0.20 \pm 0.01^{++}$ \\
\hline 21 & IAPT & $35 \pm 7$ & $-0.10 \pm 0.01$ & $26 \pm 4$ & $-0.10 \pm 0.01$ & $32 \pm 8$ & $-0.07 \pm 0.01^{++}$ & $83 \pm 21^{* *}$ & $-0.22 \pm 0.01^{++}$ \\
\hline
\end{tabular}

${ }^{a}$ Comparison with the $K_{\mathrm{B}}$ value at $\mathrm{hH}_{2} \mathrm{R}-\mathrm{G}_{\mathrm{s} \alpha \mathrm{S}} ; *, p<0.05 ; * *, p<0.01$

${ }^{b}$ Comparison with Inv. Ago. Eff. at $\mathrm{hH}_{2} \mathrm{R}_{-} \mathrm{G}_{\mathrm{s} \alpha \mathrm{S}} ;{ }^{+}, p<0.05 ;{ }^{++}, p<0.01$.

$\mathrm{hH}_{2} \mathrm{R}-\mathrm{G}_{\mathrm{s} \alpha \mathrm{S}}$. However, this correlation was determined by ligand-specific interactions, namely, the high potencies of guanidines (8 to 10) and $N^{\mathrm{G}}$-acylguanidines (11 to 16) at $\mathrm{gpH}_{2} \mathrm{R}-\mathrm{G}_{\mathrm{s} \alpha \mathrm{S}}$ (Kelley et al., 2001; Xie et al., 2006a,b), and disappeared if only compounds $\mathbf{1}$ to $\mathbf{7}$ and $\mathbf{1 7}$ to $\mathbf{2 1}$ were considered ( $r^{2}=0.04 ; p=0.527$ ). The efficacies of compounds $\mathbf{1}$ to 21 at $\mathrm{rH}_{2} \mathrm{R}-\mathrm{G}_{\mathrm{s} \alpha \mathrm{S}}$ and $\mathrm{hH}_{2} \mathrm{R}-\mathrm{G}_{\mathrm{s} \alpha \mathrm{S}}$ were almost identical (Fig. 4C). Moreover, no correlation between the log (potency ratio) and the efficacies at $\mathrm{hH}_{2} \mathrm{R}-\mathrm{G}_{\mathrm{s} \alpha \mathrm{S}}$ was evident $\left(r^{2}=0.16\right.$; $p=0.077$ ) (Fig. 4D). Thus, in the steady-state GTPase assay, $\mathrm{rH}_{2} \mathrm{R}-\mathrm{G}_{\mathrm{s} \alpha \mathrm{S}}$ and $\mathrm{hH}_{2} \mathrm{R}-\mathrm{G}_{\mathrm{s} \alpha \mathrm{S}}$ exhibited similar levels of constitutive activities. By contrast, $\mathrm{cH}_{2} \mathrm{R}-\mathrm{G}_{\mathrm{s} \alpha \mathrm{S}}$ showed the hallmarks of a GPCR with increased constitutive activity compared with $\mathrm{hH}_{2} \mathrm{R}-\mathrm{G}_{\mathrm{s} \alpha \mathrm{S}}$. Specifically, partial agonists 5 to $\mathbf{7}$ and 14 were considerably more efficacious at $\mathrm{cH}_{2} \mathrm{R}-\mathrm{G}_{\mathrm{s} \alpha \mathrm{S}}$ and the inverse agonist efficacies of antagonists 18 to 21 were increased compared with $\mathrm{hH}_{2} \mathrm{R}-\mathrm{G}_{\mathrm{s} \alpha \mathrm{S}}$ (Fig. 4E). A highly significant correlation between the log (potency ratio) and the efficacies of compounds $\mathbf{1}$ to $\mathbf{2 1}$ at $\mathrm{hH}_{2} \mathrm{R}-\mathrm{G}_{\mathrm{s} \alpha \mathrm{S}}$ was determined $\left(r^{2}=0.77 ; p<0.0001\right.$; Fig. $\left.4 \mathrm{~F}\right)$. It is noteworthy that this correlation was independent of distinct interactions of guanidines and $N^{\mathrm{G}}$-acylguanidines with $\mathrm{cH}_{2} \mathrm{R}-\mathrm{G}_{\mathrm{s} \alpha \mathrm{S}}$ as omitting compounds 8 to 16 did not change the fit $\left(r^{2}=0.75 ; p=\right.$ 0.0003).

Ambiguous Response of Metiamide (22) in the GTPase Assay. At $\mathrm{hH}_{2} \mathrm{R}-\mathrm{G}_{\mathrm{s} \alpha \mathrm{S}}$, metiamide (22) decreased the basal GTPase signal by $8 \pm 1 \%$ and thus acted as weak inverse agonist (Table 1; Fig. 5). At $\mathrm{gpH}_{2} \mathrm{R}-\mathrm{G}_{\mathrm{s} \alpha \mathrm{S}}$ and $\mathrm{rH}_{2} \mathrm{R}$ $\mathrm{G}_{\mathrm{s} \alpha \mathrm{S}}$, metiamide inhibited the basal GTPase signals by $6 \pm 1$ and $4 \pm 1 \%$, respectively, and was $\sim 2$-fold more potent than at $\mathrm{hH}_{2} \mathrm{R}-\mathrm{G}_{\mathrm{s} \alpha \mathrm{S}}$. Intriguingly, at $\mathrm{cH}_{2} \mathrm{R}-\mathrm{G}_{\mathrm{s} \alpha \mathrm{S}}$ metiamide did not act as an inverse agonist but rather as a very weak partial agonist (efficacy of $6 \pm 1 \%$ ). This is in marked contrast to the results of antagonists $\mathbf{1 8}$ to $\mathbf{2 1}$ reducing the basal GTPase signal at $\mathrm{cH}_{2} \mathrm{R}-\mathrm{G}_{\mathrm{s} \alpha \mathrm{S}}$ (increased constitutive activity) more effectively than at the other less constitutively active species. Furthermore, the potency of $\mathbf{2 2}$ was lowered by approximately 15-fold compared with $\mathrm{hH}_{2} \mathrm{R}-\mathrm{G}_{\mathrm{s} \alpha \mathrm{S}}$ and not increased as would have been expected for a partial agonist (Samama et al., 1993). Attempts to detect changes in AC activity upon stimulation with metiamide in membranes coexpressing $\mathrm{cH}_{2} \mathrm{R}$ and $\mathrm{G}_{\mathrm{s} \alpha \mathrm{S}}$ failed due to the much lower sensitivity of this system compared with the GTPase activity assay using fusion proteins (data not shown).
Regulation of AC Activities in Membranes Expressing Fused and Nonfused $\mathrm{H}_{2} \mathbf{R}$ Species Isoforms. AC activity was measured in Sf9 cell membranes expressing $\mathrm{H}_{2} \mathrm{Rs}$ (coupling to endogenous $\mathrm{G}_{\mathrm{s} \alpha}$-like $\mathrm{G}$ proteins), in membranes coexpressing $\mathrm{H}_{2} \mathrm{R}$ and mammalian $\mathrm{G}_{\mathrm{s} \alpha \mathrm{S}}$, and in membranes expressing $\mathrm{H}_{2} \mathrm{R}-\mathrm{G}_{\mathrm{s} \alpha \mathrm{S}}$ fusion proteins. Basal AC activities were similar in membranes expressing $\mathrm{hH}_{2} \mathrm{R}, \mathrm{gpH}_{2} \mathrm{R}$, and $\mathrm{rH}_{2} \mathrm{R}$ (Table 3) and $\sim 2$-fold higher in the case of the $\mathrm{cH}_{2} \mathrm{R}$. GTP $(10 \mu \mathrm{M})$ by itself increased AC activities at all four $\mathrm{H}_{2} \mathrm{R}$ species by $\sim 2$-fold above the basal level. HA (1) further increased, and IAPT (21) inhibited this GTP-dependent signal increase, indicative for constitutive activity of all four $\mathrm{H}_{2} \mathrm{R}$ species isoforms in Sf9 membranes (Fig. 6, A-D). These observations are in agreement with previous studies at the $\beta_{2} \mathrm{AR}$ (Seifert et al., 1998a). The stimulatory effects of GTP, as determined by relating the effects of GTP $(10 \mu \mathrm{M})$ to the effects of HA $(100 \mu \mathrm{M})$ plus GTP $(10 \mu \mathrm{M})$, were largest at $\mathrm{cH}_{2} \mathrm{R}$ and $\mathrm{rH}_{2} \mathrm{R}$, compared with $\mathrm{hH}_{2} \mathrm{R}$ and $\mathrm{gpH}_{2} \mathrm{R}$. Both the high basal AC activity and the strong stimulation with GTP indicate an elevated level of constitutive activity in membranes expressing the $\mathrm{cH}_{2} \mathrm{R}$ relative to membranes expressing $\mathrm{hH}_{2} \mathrm{R}, \mathrm{gpH}_{2} \mathrm{R}$, and $\mathrm{rH}_{2} \mathrm{R}$. It is noteworthy that the constitutive activity of $\mathrm{rH}_{2} \mathrm{R}$ seemed to be slightly increased compared with $\mathrm{hH}_{2} \mathrm{R}$ and $\mathrm{gpH}_{2} \mathrm{R}$.

The GPCR/G protein stoichiometry affects the magnitude of response (Kenakin, 2001). In $\mathrm{H}_{2} \mathrm{R}$ membranes coexpressing mammalian $\mathrm{G}_{\mathrm{s} \alpha \mathrm{S}}$, 5- to 18-fold increased basal levels of $\mathrm{AC}$ activity were measured relative to membranes expressing $\mathrm{H}_{2} \mathrm{R}$ alone (Table 3 ). Basal AC activities were $\sim 6$-fold higher at $\mathrm{cH}_{2} \mathrm{R}$ plus $\mathrm{G}_{\mathrm{s} \alpha \mathrm{S}}$ and $\sim 2$-fold higher at $\mathrm{rH}_{2} \mathrm{R}$ plus $\mathrm{G}_{\mathrm{s} \alpha \mathrm{S}}$, respectively, compared with $\mathrm{hH}_{2} \mathrm{R}$ plus $\mathrm{G}_{\mathrm{s} \alpha \mathrm{S}}$. With $\mathrm{gpH}_{2} \mathrm{R}$ plus $\mathrm{G}_{\mathrm{s} \alpha \mathrm{S}}$, the basal AC activity was somewhat lower than with $\mathrm{hH}_{2} \mathrm{R}$ plus $\mathrm{G}_{\mathrm{s} \alpha \mathrm{S}}$. As was observed in membranes expressing $\mathrm{H}_{2} \mathrm{R}$ alone, the highest stimulatory effects of GTP in the coexpression system were observed with $\mathrm{cH}_{2} \mathrm{R}$ and $\mathrm{rH}_{2} \mathrm{R}$ compared with $\mathrm{gpH}_{2} \mathrm{R}$ and $\mathrm{hH}_{2} \mathrm{R}$. The inverse agonist IAPT (10 $\mu \mathrm{M})$ decreased the GTP-dependent increases of AC activity at all species isoforms (Fig. 6, E-H), but even strongly reduced basal AC activities at the lowest concentrations of added GTP. These effects were probably due to traces of GDP being converted to GTP by the action of nucleoside diphosphate kinase and were most prominent in membranes expressing $\mathrm{cH}_{2} \mathrm{R}$ plus $\mathrm{G}_{\mathrm{s} \alpha \mathrm{S}}(\sim 69 \%$ reduction below basal) and $\mathrm{rH}_{2} \mathrm{R}$ plus $\mathrm{G}_{\mathrm{s} \alpha \mathrm{S}}\left(\sim 59 \%\right.$ reduction), compared with $\mathrm{hH}_{2} \mathrm{R}$ plus 



Fig. 4. Efficacies and potencies of ligands 1 to 21 at $\mathrm{hH}_{2} \mathrm{R}-\mathrm{G}_{\mathrm{s \alpha S}}$ in pairwise comparison with $\mathrm{gpH}_{2} \mathrm{R}-\mathrm{G}_{\mathrm{s} \alpha \mathrm{S}}, \mathrm{rH}_{2} \mathrm{R}-\mathrm{G}_{\mathrm{s} \alpha \mathrm{S}}$, and $\mathrm{cH}_{2} \mathrm{R}-\mathrm{G}_{\mathrm{s} \alpha \mathrm{S}}$, respectively, as determined in the steady-state GTPase assay. GTPase activity in Sf9 membranes was measured as described under Materials and Methods. Data shown are the means taken from Tables 1 and 2. A, C, and $\mathrm{E}$, relation between the efficacies of compounds 1 to 21 at $\mathrm{hH}_{2} \mathrm{R}-\mathrm{G}_{\mathrm{s} \alpha \mathrm{S}}$ versus $\mathrm{gpH}_{2} \mathrm{R}-\mathrm{G}_{\mathrm{s} \alpha \mathrm{S}}(\mathrm{A}), \mathrm{rH}_{2} \mathrm{R}-\mathrm{G}_{\mathrm{s} \alpha \mathrm{S}}(\mathrm{C})$, and $\mathrm{cH}_{2} \mathrm{R}-\mathrm{G}_{\mathrm{s} \alpha \mathrm{S}}(\mathrm{E})$, respectively. The dashed line has a slope of 1.0 and represents a theoretical curve of identical efficacies in both systems. B, D, and F, relation between log (potency ratio) of compounds 1 to 21 at $\mathrm{gpH}_{2} \mathrm{R}-\mathrm{G}_{\mathrm{s} \alpha \mathrm{S}}(\mathrm{B}), \mathrm{rH}_{2} \mathrm{R}-\mathrm{G}_{\mathrm{s} \alpha \mathrm{S}}$ (D), and $\mathrm{cH}_{2} \mathrm{R}-\mathrm{G}_{\mathrm{s \alpha S}}(\mathrm{F})$, respectively, and the corresponding efficacies at $\mathrm{hH}_{2} \mathrm{R}-\mathrm{G}_{\mathrm{s} \alpha \mathrm{S}}$. The potency ratio is the ratio of $\mathrm{EC}_{50}$ values of full and partial agonists (1-16) at $\mathrm{hH}_{2} \mathrm{R}-\mathrm{G}_{\mathrm{s} \alpha \mathrm{S}}$ and at $\mathrm{gpH}_{2} \mathrm{R}-\mathrm{G}_{\mathrm{s} \alpha \mathrm{S}}, \mathrm{rH}_{2} \mathrm{R}-\mathrm{G}_{\mathrm{s} \alpha \mathrm{S}}$, and $\mathrm{cH}_{2} \mathrm{R}$ $\mathrm{G}_{\mathrm{s \alpha S}}$, respectively. Accordingly, the potency ratio of antagonists (17-21) is the ratio of the corresponding $K_{\mathrm{B}}$ values at $\mathrm{hH}_{2} \mathrm{R}-\mathrm{G}_{\mathrm{s} \alpha \mathrm{S}}$ and at $\mathrm{gpH}_{2} \mathrm{R}-\mathrm{G}_{\mathrm{s} \alpha \mathrm{S}}$, $\mathrm{rH}_{2} \mathrm{R}-\mathrm{G}_{\mathrm{s} \alpha \mathrm{S}}$, and $\mathrm{cH}_{2} \mathrm{R}-\mathrm{G}_{\mathrm{s} \alpha \mathrm{S}}$, respectively. The vertical dashed line intersects the abscissa at 0.0 and represents a theoretical curve of identical potencies in both systems.

$\mathrm{G}_{\mathrm{s} \alpha \mathrm{S}}(\sim 29 \%$ reduction $)$ and $\mathrm{gpH}_{2} \mathrm{R}$ plus $\mathrm{G}_{\mathrm{s} \alpha \mathrm{S}}(\sim 23 \%$ reduction). Taken together, among $\mathrm{H}_{2} \mathrm{R}$ species isoforms coexpressed with $\mathrm{G}_{\mathrm{s} \alpha \mathrm{S}}, \mathrm{cH}_{2} \mathrm{R}$ was the most constitutively active GPCR.

Due to the efficient coupling of the signaling partners in GPCR-G $\mathrm{s}_{\mathrm{s}} \alpha$ fusion proteins (Seifert et al., 1999), in membranes expressing $\mathrm{H}_{2} \mathrm{R}-\mathrm{G}_{\mathrm{s} \alpha \mathrm{S}}$, strongly elevated basal AC activities were measured, compared with membranes express-

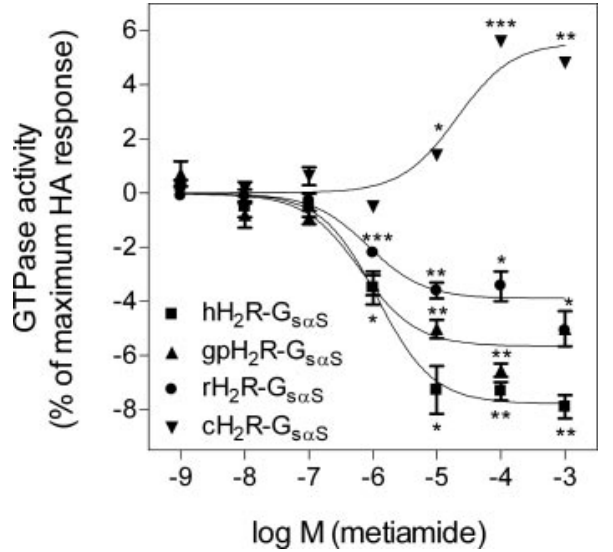

Fig. 5. Effects of metiamide on GTPase activity in membranes expressing $\mathrm{H}_{2} \mathrm{R}-\mathrm{G}_{\mathrm{s} \alpha \mathrm{S}}$ species isoforms. GTPase activity in Sf9 membranes was determined as described under Materials and Methods. Reaction mixtures contained membranes $\left(10 \mu \mathrm{g}\right.$ of protein/tube) expressing $\mathrm{hH}_{2} R-\mathrm{G}_{\mathrm{s} \alpha \mathrm{S}}$, $\mathrm{gpH}_{2} \mathrm{R}-\mathrm{G}_{\mathrm{s} \alpha \mathrm{S}}, \mathrm{rH}_{2} \mathrm{R}-\mathrm{G}_{\mathrm{s} \alpha \mathrm{S}}$, and $\mathrm{cH}_{2} \mathrm{R}-\mathrm{G}_{\mathrm{s} \alpha \mathrm{S}}$ fusion proteins and metiamide at concentrations indicated on the abscissa. Data are expressed as percentage change in GTPase activity induced by metiamide compared with the GTPase activity stimulated by HA $(100 \mu \mathrm{M})$. Data shown are the means \pm S.E.M. of three independent experiments performed in duplicates. Data were analyzed by nonlinear regression and were best fitted to sigmoidal concentration-response curves. The significance of the deviation from zero was calculated for each mean value using $t$ test; $*, p<0.05$; $* *, p<0.01 ; * * *, p<0.001$.

ing nonfused $\mathrm{H}_{2}$ Rs coexpressing $\mathrm{G}_{\mathrm{s} \alpha \mathrm{S}}$ (Table 3 ). In agreement with the results obtained for membranes expressing nonfused $\mathrm{H}_{2} \mathrm{Rs}$, among the four species isoforms, $\mathrm{cH}_{2} \mathrm{R}-\mathrm{G}_{\mathrm{s} \alpha \mathrm{S}}$ and $\mathrm{rH}_{2} \mathrm{R}-\mathrm{G}_{\mathrm{s} \alpha \mathrm{S}}$ exhibited the highest basal AC activities. As shown in Fig. 6, K and L, GTP increased AC activity in those membranes so effectively that HA could not produce a further increase, reflecting exhaustion of the limiting pool of AC molecules (Seifert at al., 1998a). At $\mathrm{hH}_{2} \mathrm{R}-\mathrm{G}_{\mathrm{s} \alpha \mathrm{S}}$ and $\mathrm{gpH}_{2} \mathrm{R}$ $\mathrm{G}_{\mathrm{s} \alpha \mathrm{S}}$, GTP induced only smaller increases, allowing HA to further enhance AC activity. By contrast, in the absence of added GTP, HA (100 $\mu \mathrm{M})$ yielded a reduction of basal AC activities at all four species (Fig. 6, I-L). Very similar effects were observed previously for the $\beta_{2} A R-G_{\mathrm{s} \alpha \mathrm{S}}$ fusion protein (Seifert et al., 1998b) and are due to dissociation of GDP from $\mathrm{G}_{\mathrm{s} \alpha \mathrm{S}}$ following agonist binding to the receptor without subsequent binding of GTP. Because $\mathrm{G}_{\mathrm{s} \alpha \text {-GDP }}$ is more effective in activating $\mathrm{AC}$ than nucleotide-free $\mathrm{G}_{\mathrm{s} \alpha}$, $\mathrm{AC}$ activity was reduced below basal. Due to much less efficient coupling in membranes coexpressing receptors and $\mathrm{G}_{\mathrm{s} \alpha \mathrm{S}}$ (Seifert et al., 1998a; Houston et al., 2002; Gille and Seifert, 2003), in this case HA did not reduce basal AC activity (Fig. 6, E-H). Similar differences in the coupling efficiencies between fusion proteins and nonfused expression systems were observed in terms of ternary complex formation, guanosine 5'-O-(3-thio)triphosphate binding, GTP hydrolysis, and AC activation in the presence of GTP (Seifert et al., 1998a; Wenzel-Seifert et al., 2002; Gille and Seifert, 2003). Thus, in membranes expressing $\mathrm{H}_{2} \mathrm{R}-\mathrm{G}_{\mathrm{s} \alpha \mathrm{S}}$ fusion proteins the apparent constitutive activities were considerably higher than in membranes expressing nonfused $\mathrm{H}_{2} \mathrm{Rs}$. In the case of $\mathrm{cH}_{2} \mathrm{R}$ $\mathrm{G}_{\mathrm{s} \alpha \mathrm{S}}$ and $\mathrm{rH}_{2} \mathrm{R}-\mathrm{G}_{\mathrm{s} \alpha \mathrm{S}}$, saturation of $\mathrm{AC}$ molecules became manifest upon agonist (HA) stimulation.

\section{Discussion}

Increased Constitutive Activity of the $\mathrm{cH}_{2} \mathrm{R}$ Compared with $\mathbf{h} \mathbf{H}_{2} \mathbf{R}, \mathbf{g p H}_{2} \mathbf{R}$, and $\mathbf{r H}_{2} \mathbf{R}$. The use of GPCR- 
TABLE 3

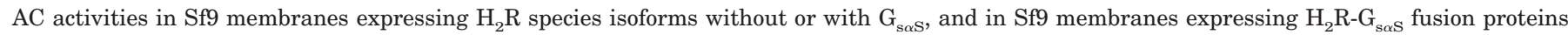

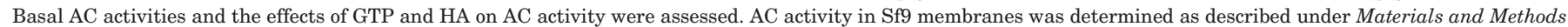

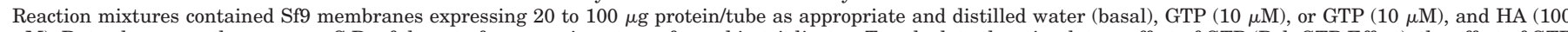

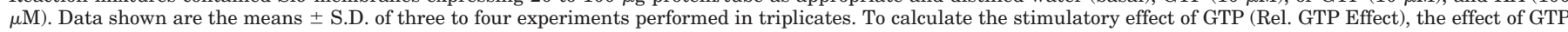

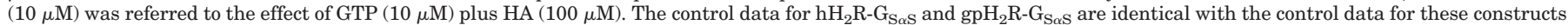
in Table 3 of Preuss et al. (2007).

\begin{tabular}{|c|c|c|c|c|}
\hline & $\begin{array}{l}\text { Basal, AC } \\
\text { Activity }\end{array}$ & $\begin{array}{c}10 \underset{\text { Activity }}{\mathrm{M} \text { GTP }}, \mathrm{AC} \\
\text {. }\end{array}$ & $\begin{array}{c}10 \mu \mathrm{M} \mathrm{GTP}+100 \mu \mathrm{M} \mathrm{HA}, \mathrm{AC} \\
\text { Activity }\end{array}$ & $\begin{array}{l}\text { Rel. GTP } \\
\text { Effect }\end{array}$ \\
\hline & \multicolumn{3}{|c|}{ pmol $\mathrm{mg}^{-1} \min ^{-1}$} & $\%$ \\
\hline $\mathrm{hH}_{2} \mathrm{R}$ & $0.3 \pm 0.0$ & $0.6 \pm 0.1$ & $3.4 \pm 0.2$ & 10 \\
\hline $\mathrm{gpH}_{2} \mathrm{R}$ & $0.3 \pm 0.1$ & $0.5 \pm 0.0$ & $2.6 \pm 0.2$ & 9 \\
\hline $\mathrm{rH}_{2} \mathrm{R}$ & $0.4 \pm 0.0$ & $0.8 \pm 0.1$ & $3.1 \pm 0.2$ & 15 \\
\hline $\mathrm{cH}_{2} \mathrm{R}$ & $0.7 \pm 0.1$ & $1.5 \pm 0.2$ & $4.3 \pm 0.7$ & 22 \\
\hline $\mathrm{hH}_{2} \mathrm{R}+\mathrm{G}_{\mathrm{s} \alpha \mathrm{S}}$ & $2.3 \pm 0.4$ & $6.3 \pm 0.8$ & $11.8 \pm 0.5$ & 42 \\
\hline $\mathrm{gpH}_{2} \mathrm{R}+\mathrm{G}_{\mathrm{s} \alpha \mathrm{S}}$ & $1.5 \pm 0.3$ & $4.4 \pm 0.5$ & $10.8 \pm 1.5$ & 31 \\
\hline $\mathrm{rH}_{2} \mathrm{R}+\mathrm{G}_{\mathrm{s} \alpha \mathrm{S}}$ & $4.9 \pm 0.4$ & $11.1 \pm 1.3$ & $16.1 \pm 0.7$ & 55 \\
\hline $\mathrm{cH}_{2} \mathrm{R}+\mathrm{G}_{\mathrm{s} \alpha \mathrm{S}}$ & $12.8 \pm 1.9$ & $24.7 \pm 4.1$ & $31.1 \pm 3.7$ & 65 \\
\hline $\mathrm{hH}_{2} \mathrm{R}-\mathrm{G}_{\mathrm{s} \alpha \mathrm{S}}$ & $12.1 \pm 2.1$ & $24.3 \pm 4.8$ & $28.7 \pm 5.3$ & 73 \\
\hline $\mathrm{gpH}_{2} \mathrm{R}-\mathrm{G}_{\mathrm{s} \alpha \mathrm{S}}$ & $13.4 \pm 3.1$ & $25.0 \pm 0.6$ & $28.5 \pm 2.2$ & 77 \\
\hline $\mathrm{rH}_{2} \mathrm{R}-\mathrm{G}_{\mathrm{s} \alpha \mathrm{S}}$ & $30.5 \pm 2.6$ & $43.5 \pm 1.7$ & $44.4 \pm 3.0$ & 94 \\
\hline $\mathrm{cH}_{2} \mathrm{R}-\mathrm{G}_{\mathrm{s} \alpha \mathrm{S}}$ & $26.3 \pm 3.6$ & $41.9 \pm 5.3$ & $40.9 \pm 5.2$ & 107 \\
\hline
\end{tabular}

$\mathrm{G}_{\mathrm{s} \alpha}$ fusion protein in combination with the determination of GTPase activity in Sf9 cell membranes was previously shown to be an appropriate system to quantify constitutive activity (Seifert et al., 1998b; Seifert and Wenzel-Seifert, 2002). This system fixes GPCR/G protein coupling and stays at a proximal level, thus avoiding potential bias caused by more downstream effects, such as effector activation or changes in gene expression. Moreover, due to the defined 1:1 stoichiometry of receptor and $G_{s \alpha}$ in fusion proteins, ligand potencies and efficacies in the steady-state GTPase assay are independent of the expression levels, allowing for the comparison of various membrane preparations with different expression levels (Seifert et al., 1999; Milligan, 2000).

We comprehensively characterized the human, guinea pig, rat, and canine $\mathrm{H}_{2} \mathrm{R}$ species isoforms in steady-state GTPase assays in Sf9 cell membranes expressing $\mathrm{H}_{2} \mathrm{R}-\mathrm{G}_{\mathrm{s} \alpha \mathrm{S}}$ fusion proteins. Structurally diverse $\mathrm{H}_{2} \mathrm{R}$ full and partial agonists and antagonists unmasked considerable differences in the constitutive activities of the receptors. Specifically, $\mathrm{cH}_{2} \mathrm{R}$ $\mathrm{G}_{\mathrm{s} \alpha \mathrm{S}}$ but neither $\mathrm{rH}_{2} \mathrm{R}-\mathrm{G}_{\mathrm{s} \alpha \mathrm{S}}$ nor $\mathrm{gpH}_{2} \mathrm{R}-\mathrm{G}_{\mathrm{s} \alpha \mathrm{S}}$ displayed the hallmarks of increased constitutive activity compared with $\mathrm{hH}_{2} \mathrm{R}_{-} \mathrm{G}_{\mathrm{s} \alpha \mathrm{S}}$ (Lefkowitz et al., 1993; Samama et al., 1993): 1) increased efficacies of partial agonists, 2) increased potencies of agonists with the extent of potency increase being correlated with the efficacy, and 3) increased inverse agonist efficacies and decreased potencies of antagonists.

The determination of AC activity in Sf9 cell membranes is an alternative and sensitive method to investigate constitutive activity of GPCRs (Seifert et al., 1998a). With respect to $\mathrm{AC}$, differences in the basal activity and in the magnitudes of signal increases upon stimulation with GTP are indicators for various levels of constitutive activity. In the AC activity assay with membranes expressing nonfused $\mathrm{H}_{2} \mathrm{R}$ species isoforms either without or together with mammalian $G_{s \alpha S}$, both effects were most pronounced for canine relative to human, guinea pig, and rat, corroborating the outstanding role of $\mathrm{cH}_{2} \mathrm{R}$ in terms of constitutive activity.

However, our analysis of AC activity in membranes expressing $\mathrm{H}_{2} \mathrm{R}$ species isoforms also illustrates the limitations of this system. Most importantly, the low concentration levels of AC molecules constrain the maximal signal output, thereby yielding large stimulatory effects of GTP and large inhibitory effects of inverse agonists on AC activity. In contrast, the stimulatory effects of the agonist HA are small, if at all detectable. In addition, in the case of the $\mathrm{rH}_{2} \mathrm{R}$, basal AC activities and the increases of AC activity upon stimulation with GTP were moderately higher compared with the $\mathrm{hH}_{2} \mathrm{R}$, whereas in the GTPase activity assay $\mathrm{rH}_{2} \mathrm{R}-\mathrm{G}_{\mathrm{s} \alpha \mathrm{S}}$ and $\mathrm{hH}_{2} \mathrm{R}$ $\mathrm{G}_{\mathrm{s} \alpha \mathrm{S}}$ showed similar constitutive activity. The accumulation of $\mathrm{rH}_{2} \mathrm{R}$ in $\mathrm{Sf9}$ cell membrane microdomains rich in $\mathrm{AC}$ molecules could be an explanation for the observed effects (Ostrom and Insel, 2004).

It is now widely accepted that GPCR activation involves disruption of an ionic lock between $\operatorname{Asp}(3.49)$ and $\operatorname{Arg}(3.50)$ of the highly conserved (E/D)RY motif in TM3 and Glu(6.30) in the cytoplasmatic extension of TM6 (Ballesteros et al., 2001; Visiers et al., 2002). The effects of mutations in the DRY motif on constitutive activity and structural instability of the rat $\mathrm{H}_{2} \mathrm{R}$ were shown previously (Alewijnse et al., 2000). Asp115(3.49), Arg-116(3.50), and Glu-228/229(6.30) are conserved among all $\mathrm{H}_{2} \mathrm{R}$ species isoforms. However, preceding Glu-229(6.30) in $\mathrm{hH}_{2} \mathrm{R}$ and $\mathrm{gpH}_{2} \mathrm{R}$ and the corresponding Glu-228(6.30) in $\mathrm{rH}_{2} \mathrm{R}$, human, guinea pig, and rat $\mathrm{H}_{2} \mathrm{Rs}$ exhibit an arginine (6.29), compared with a glycine (6.29), in $\mathrm{cH}_{2} \mathrm{R}$. Strikingly, many class A GPCRs contain a basic amino acid at the corresponding position, and accordingly, a stabilizing role of this residue in the network of ionic interactions was proposed (Ballesteros et al., 2001). Hence, the lack of this additional constraint in $\mathrm{cH}_{2} \mathrm{R}$ could facilitate the transition from the inactive to the active state, resulting in the observed enhancement in constitutive activity.

Other differences in amino acid sequences could contribute to the differences in constitutive activity as well. Specifically, in G649, an allelic variant of the $\mathrm{hH}_{2} \mathrm{R}$, Asn-217 in i3, is replaced by Asp-217. This mutant displays low basal activity and is resistant to up-regulation upon antagonist exposure (Fukushima et al., 2001). Intriguingly, Asn-217 is conserved within $\mathrm{hH}_{2} \mathrm{R}$, gpH $\mathrm{H}_{2} \mathrm{R}$, and $\mathrm{rH}_{2} \mathrm{R}$, but it is replaced by a histidine in $\mathrm{cH}_{2} \mathrm{R}$. Moreover, major variations in the sequences of $\mathrm{H}_{2} \mathrm{R}$ species isoforms occur in the $\mathrm{C}$-terminal domain. Because the $\mathrm{C}$ terminus of $\mathrm{H}_{2} \mathrm{R}$ is important for $\mathrm{G}_{\mathrm{s}}$ protein activation (Smit et al., 1996), the observed variations in the constitutive activities may alternatively or additionally be due to differences in this domain. In fact, an influence of the 

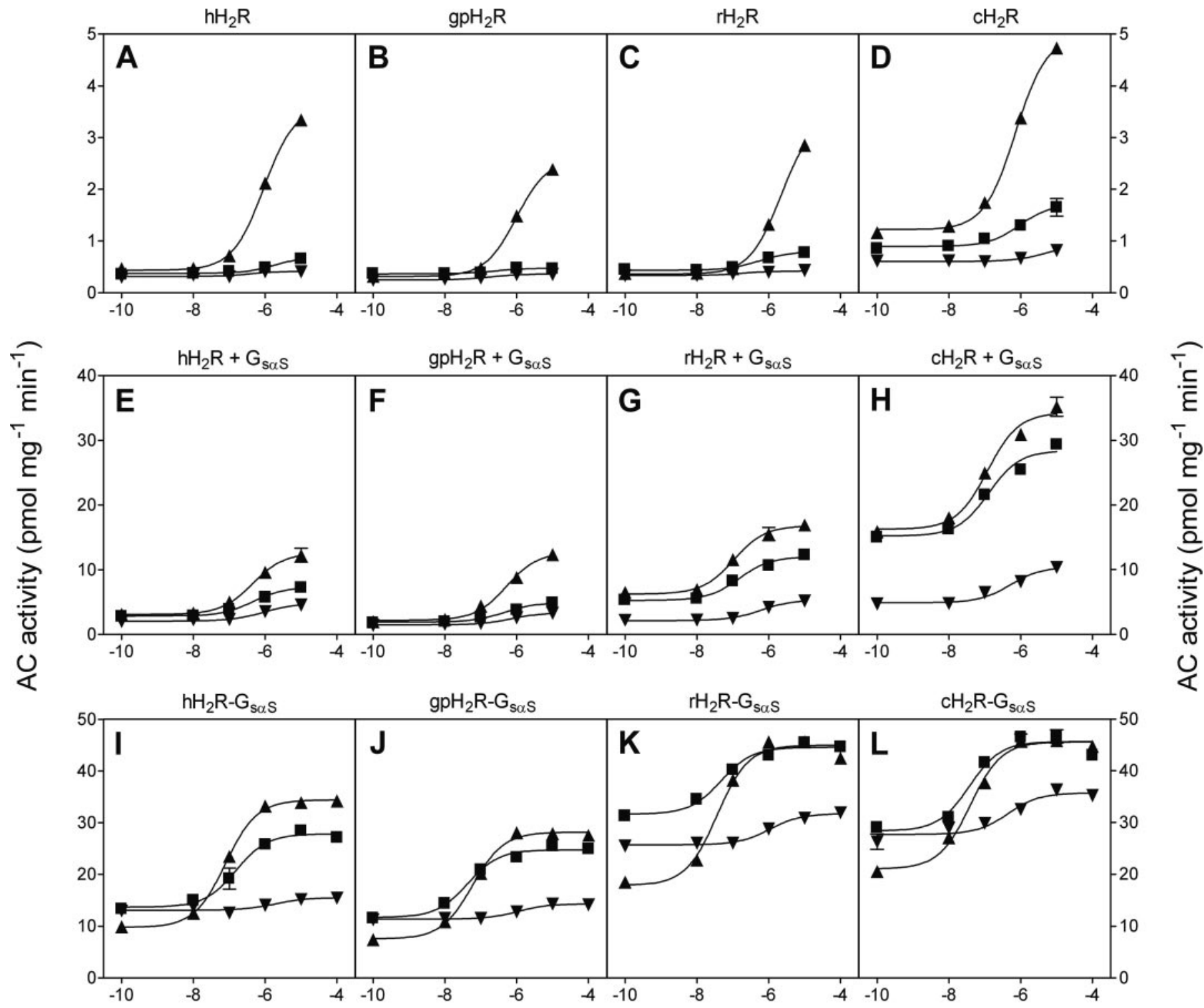

\section{GTP $(\log M)$}

Fig. 6. Regulation of $A C$ activities in $S f 9$ membranes expressing $H_{2} R$ species isoforms $(A-D), H_{2} R$ species isoforms plus $G_{s \alpha S}(E-H)$, or $H_{2} R-G_{s \alpha S}$ fusion proteins (I-L). AC activity in Sf9 membranes was determined as described under Materials and Methods. Reaction mixtures contained Sf9 membranes expressing the proteins indicated on top of each panel and GTP at concentrations indicated at the abscissa. Reaction mixtures additionally contained $\mathrm{H}_{2} \mathrm{O}(\boldsymbol{\square})$, HA $(100 \mu \mathrm{M})(\boldsymbol{\Delta})$, or IAPT $(10 \mu \mathrm{M})(\boldsymbol{\nabla})$. Data shown are the means \pm S.E.M. of one representative experiment performed in duplicates. The statistical analysis of AC activities is provided in Table 3. Data were analyzed by nonlinear regression and were best fitted to sigmoidal concentrationresponse curves. The control data for $\mathrm{hH}_{2} \mathrm{R}-\mathrm{G}_{\mathrm{S} \alpha \mathrm{S}}$ and $\mathrm{gpH}_{2} \mathrm{R}-\mathrm{G}_{\mathrm{S \alpha S}}$ are identical with the control data for these constructs in Fig. 4 of Preuss et al. (2007).

C terminus on the constitutive activities of various GPCRs was described previously (Prezeau et al., 1996; WenzelSeifert and Seifert, 2003).

Ligand-Specific Interactions at $\mathbf{H}_{2} R$ Species Isoforms. In the GTPase activity assay, $N$-[3-( $1 H$-imidazol-4yl)propyl]guanidines and their $N^{\mathrm{G}}$-acylated analogs were more potent and more efficacious at $\mathrm{gpH}_{2} \mathrm{R}-\mathrm{G}_{\mathrm{s} \alpha \mathrm{S}}$ than at $\mathrm{hH}_{2} \mathrm{R}-\mathrm{G}_{\mathrm{s} \alpha \mathrm{S}}$, which is in agreement with previous studies (Kelley et al., 2001; Xie et al., 2006a). Because both species isoforms exhibit similar constitutive activities, our present data further support the concept of distinct interactions as a rationale for this species selectivity. As was predicted by molecular modeling studies and subsequently verified by site-directed mutagenesis, the species selectivity of guanidine-type agonists is based on two distinct amino acids, Tyr17(1.31) in TM1 and Asp-271(7.36) in TM7 in the $\mathrm{gpH}_{2} \mathrm{R}$, presumably interacting via a charge assisted $\mathrm{H}$-bond and thereby stabilizing an active agonist-bound conformation (Kelley et al., 2001). In the $\mathrm{hH}_{2} \mathrm{R}$ [Cys-17(1.31), Ala-271(7.36)] and the $\mathrm{rH}_{2} \mathrm{R}$ [Leu-17(1.31), Gly-270(7.36)], this interaction is impossible. Consistently, the guanidinetype agonists were similarly efficacious and potent at $\mathrm{rH}_{2} \mathrm{R}$ $\mathrm{G}_{\mathrm{s} \alpha \mathrm{S}}$ and $\mathrm{hH}_{2} \mathrm{R}-\mathrm{G}_{\mathrm{s} \alpha \mathrm{S}}$. Both $\mathrm{cH}_{2} \mathrm{R}$ and $\mathrm{hH}_{2} \mathrm{R}$ contain Cys17(1.31) and Ala-271(7.36) and the differences in potencies and efficacies of the compounds between $\mathrm{cH}_{2} \mathrm{R}-\mathrm{G}_{\mathrm{s} \alpha \mathrm{S}}$ and $\mathrm{hH}_{2} \mathrm{R}-\mathrm{G}_{\mathrm{s} \alpha \mathrm{S}}$ were not specific to the guanidines. Thus, these 
differences can be explained by the increased constitutive activity of $\mathrm{cH}_{2} \mathrm{R}-\mathrm{G}_{\mathrm{s} \alpha \mathrm{S}}$ rather than by distinct ligand/GPCR interactions.

Recently, certain $N^{\mathrm{G}}$-acylated guanidines have shown to be more efficacious than $\mathrm{HA}$ at $\mathrm{gpH}_{2} \mathrm{R}-\mathrm{G}_{\mathrm{s} \alpha \mathrm{S}}$ in the GTPase assay (Xie et al., 2006b), similar to the observations made with UR-PG222A (13) in the present study. These effects can be attributed to the concept of ligand-specific $\mathrm{gpH}_{2} \mathrm{R}$ conformations as well, i.e., these compounds stabilize active $\mathrm{gpH}_{2} \mathrm{R}$ conformations that lead to more efficient interactions with $\mathrm{G}_{\mathrm{s} \alpha \mathrm{S}}$ than achieved with the endogenous ligand HA. By analogy, at the $\beta_{2} \mathrm{AR}$ labeled with a fluorescent probe, the synthetic ligand isoproterenol induced a stronger change in fluorescence intensity than the endogenous ligand norepinephrine (Swaminath et al., 2004).

A further example of ligand-specific interactions at $\mathrm{H}_{2} \mathrm{R}$ species isoforms is given by metiamide, acting as a weak partial agonist with low potency at $\mathrm{cH}_{2} \mathrm{R}-\mathrm{G}_{\mathrm{s} \alpha \mathrm{S}}$ in the GTPase assay compared with being an inverse agonist with increased potency at human, guinea pig, and rat $\mathrm{H}_{2} \mathrm{R}-\mathrm{G}_{\mathrm{s} \alpha \mathrm{S}}$. Moreover, in contrast to increased inverse agonist efficacies of antagonists 18 to 21 at $c H_{2} R-G_{s \alpha S}$ relative to $h H_{2} R-G_{s \alpha S}, g p H_{2} R$ $\mathrm{G}_{\mathrm{s} \alpha \mathrm{S}}$, and $\mathrm{rH}_{2} \mathrm{R}-\mathrm{G}_{\mathrm{s} \alpha \mathrm{S}}$, the inverse agonist efficacies of cimetidine (17), a cyanoguanidine analog of metiamide, were similar at all four species whereas its potency was significantly decreased at $\mathrm{cH}_{2} \mathrm{R}-\mathrm{G}_{\mathrm{s} \alpha \mathrm{S}}$. Presumably because of the common 2[(5-methylimidazol-4-yl)methylthio]ethyl moiety, both metiamide and cimetidine stabilize distinct conformations in $\mathrm{cH}_{2} \mathrm{R}$ relative to the other species isoforms, thus leading to an altered interaction with $\mathrm{G}_{\mathrm{s} \alpha \mathrm{S}}$, which, in the extreme case of metiamide, causes weak partial agonism rather than increased inverse agonism.

\section{Conclusions}

In the present study, we demonstrate that the $\mathrm{cH}_{2} \mathrm{R}$ exhibits increased constitutive activity compared with $\mathrm{hH}_{2} \mathrm{R}$, $\mathrm{gpH}_{2} \mathrm{R}$, and $\mathrm{rH}_{2} \mathrm{R}$. Species-specific differences in constitutive activity were previously reported for the cholecystokinin-B/ gastrin receptor that, like the $\mathrm{H}_{2} \mathrm{R}$, stimulates gastric $\mathrm{H}^{+}$ production (Kopin et al., 2000). Thus, differences in constitutive activities of GPCRs regulating $\mathrm{H}^{+}$production may reflect species-specific requirements for "basal" and peak $\mathrm{H}^{+}$ secretion in the stomach. For example, following stimulation with HA, gastric acid secretion rates in dogs exceed those of the human (Kararli, 1995). Moreover, by studying the $\mathrm{H}_{2} \mathrm{R}$ antagonist metiamide, further evidence for ligand-specific conformations of $\mathrm{H}_{2} \mathrm{R}$ species isoforms was obtained. Our present study validates the notion that quantitative comparison of species isoforms of GPCRs provides unique insights into the molecular mechanisms of GPCR activation and ligand/GPCR interactions.

\section{Acknowledgments}

We thank Dr. I. Gantz for providing the $\mathrm{cDNA}$ of $\mathrm{cH}_{2} \mathrm{R}$ and Dr. $\mathrm{R}$. Leurs for providing the cDNA of $\mathrm{rH}_{2} \mathrm{R}$. We also thank Dr. E. Schneider (Department of Pharmacology and Toxicology, University of Regensburg, Regensburg, Germany) for helpful discussions and G. Wilberg for technical support.

\section{References}

Alewijnse AE, Smit MJ, Hoffmann M, Verzijl D, Timmerman H, and Leurs R (1998) Constitutive activity and structural instability of the wild-type human $\mathrm{H}_{2}$ receptor. J Neurochem 71:799-807.
Alewijnse AE, Timmerman H, Jacobs EH, Smit MJ, Roovers E, Cotecchia S, and Leurs R (2000) The effect of mutations in the DRY motif on the constitutive activity and structural instability of the histamine $\mathrm{H}_{2}$ receptor. Mol Pharmacol $\mathbf{5 7 : 8 9 0 - 8 9 8}$

Ballesteros JA, Jensen AD, Liapakis G, Rasmussen SG, Shi L, Gether U, and Javitch JA (2001) Activation of the $\beta_{2}$-adrenergic receptor involves disruption of an ionic lock between the cytoplasmic ends of transmembrane segments 3 and 6. J Biol Chem 276:29171-29177.

Cheng Y and Prusoff WH (1973) Relationship between the inhibition constant $\left(K_{\mathrm{i}}\right)$ and the concentration of inhibitor which causes 50 per cent inhibition $\left(\mathrm{I}_{50}\right)$ of an enzymatic reaction. Biochem Pharmacol 22:3099-3108.

Dove S, Elz S, Seifert R, and Buschauer A (2004) Structure-activity relationships of histamine $\mathrm{H}_{2}$ receptor ligands. Mini Rev Med Chem 4:941-954.

Elz S, Kramer K, Pertz HH, Detert H, ter Laak AM, Kühne R, and Schunack W (2000) Histaprodifens: synthesis, pharmacological in vitro evaluation, and molec ular modeling of a new class of highly active and selective histamine $\mathrm{H}_{1}$-receptor agonists. J Med Chem 43:1071-1084.

Fukushima Y, Asano T, Saitoh T, Anai M, Funaki M, Ogihara T, Katagiri H, Matsuhashi N, Yazaki Y, and Sugano K (1997) Oligomer formation of histamine $\mathrm{H}_{2}$ receptors expressed in Sf9 and COS7 cells. FEBS Lett 409:283-286.

Fukushima Y, Oka Y, Saitoh T, Katagiri H, Asano T, Matsuhashi N, Takata K, van Breda E, Yazaki Y, and Sugano K (1995) Structural and functional analysis of the canine histamine $\mathrm{H}_{2}$ receptor by site-directed mutagenesis: $\mathrm{N}$-glycosylation is not vital for its action. Biochem $J$ 310:553-558.

Fukushima Y, Saitoh T, Anai M, Tsukuda K, Onishi Y, Sakoda H, Inukai K, Ogihara T, Funaki M, Ono H, et al. (2001) G649, an allelic variant of the human $\mathrm{H}_{2}$ receptor with low basal activity, is resistant to upregulation upon antagonist exposure. Pharmacogenomics $J$ 1:78-83.

Gantz I, DelValle J, Wang LD, Tashiro T, Munzert G, Guo YJ, Konda Y, and Yamada $\mathrm{T}$ (1992) Molecular basis for the interaction of histamine with the histamine $\mathrm{H}_{2}$ receptor. J Biol Chem 267:20840-20843.

Gantz I, Munzert G, Tashiro T, Schäffer M, Wang L, DelValle J, and Yamada T (1991a) Molecular cloning of the human histamine $\mathrm{H}_{2}$ receptor. Biochem Biophys Res Commun 178:1386-1392.

Gantz I, Schäffer M, DelValle J, Logsdon C, Campbell V, Uhler M, and Yamada T (1991b) Molecular cloning of a gene encoding the histamine $\mathrm{H}_{2}$ receptor. Proc Natl Acad Sci USA 88:429-433.

Ghorai P (2005) Arpromidine-Related Acylguanidines: Synthesis and StructureActivity Relationships of a New Class of Guanidine-Type Histamine $\mathrm{H}_{2}$ Receptor Agonists with Reduced Basicity. Ph.D. thesis. University of Regensburg, Regensburg, Germany.

Gille A and Seifert R (2003) Co-expression of the $\beta_{2}$-adrenoceptor and dopamine $D_{1}$-receptor with $G_{\mathrm{s} \alpha}$ proteins in Sf9 insect cells: limitations in comparison with fusion proteins. Biochim Biophys Acta 1613:101-114.

Hill SJ, Ganellin CR, Timmerman H, Schwartz JC, Shankley NP, Young JM, Schunack W, Levi R, and Haas HL (1997) International Union of Pharmacology. XIII. Classification of histamine receptors. Pharmacol Rev 49:253-278.

Houston C, Wenzel-Seifert K, Bürckstümmer T, and Seifert R (2002) The human histamine $\mathrm{H}_{2}$-receptor couples more efficiently to $\mathrm{Sf} 9$ insect cell $\mathrm{G}_{\mathrm{s}}$-proteins than to insect cell $\mathrm{G}_{\mathrm{q}}$-proteins: limitations of $\mathrm{Sf} 9$ cells for the analysis of receptor/ $\mathrm{G}_{\mathrm{q}}$ protein coupling. J Neurochem 80:678-696.

Kararli TT (1995) Comparison of the gastrointestinal anatomy, physiology, and biochemistry of humans and commonly used laboratory animals. Biopharm Drug Dispos 16:351-380.

Kelley MT, Bürckstümmer T, Wenzel-Seifert K, Dove S, Buschauer A, and Seifert R (2001) Distinct interaction of human and guinea pig histamine $\mathrm{H}_{2}$-receptor with guanidine-type agonists. Mol Pharmacol 60:1210-1225.

Kenakin T (2001) Inverse, protean, and ligand-selective agonism: matters of receptor conformation. FASEB J 15:598-611.

Kopin AS, McBride EW, Schaffer K, and Beinborn M (2000) CCK receptor polymorphisms: an illustration of emerging themes in pharmacogenomics. Trends Phar macol Sci 21:346-353.

Lefkowitz RJ, Cotecchia S, Samama P, and Costa T (1993) Constitutive activity of receptors coupled to guanine nucleotide regulatory proteins. Trends Pharmacol Sci 14:303-307.

Milligan G (2000) Insights into ligand pharmacology using receptor-G-protein fusion proteins. Trends Pharmacol Sci 21:24-28.

Nederkoorn PH, van Gelder EM, Donne-Op den Kelder GM, and Timmerman H (1996) The agonistic binding site at the histamine $\mathrm{H}_{2}$ receptor. II. Theoretical investigations of histamine binding to receptor models of the seven $\alpha$-helical transmembrane domain. J Comput Aided Mol Des 10:479-489.

Ostrom RS and Insel PA (2004) The evolving role of lipid rafts and caveolae in G protein-coupled receptor signaling: implications for molecular pharmacology. $\mathrm{Br} J$ Pharmacol 143:235-245.

Preuss H, Ghorai P, Kraus A, Dove S, Buschauer A, and Seifert R (2007) Mutation of Cys-17 and Ala-271 in the human histamine $\mathrm{H}_{2}$ receptor determines the species selectivity of guanidine-type agonists and increase constitutive activity. J Phar macol Exp Ther 321:975-982.

Prezeau L, Gomeza J, Ahern S, Mary S, Galvez T, Bockaert J, and Pin JP (1996) Changes in the carboxyl-terminal domain of metabotropic glutamate receptor 1 by alternative splicing generate receptors with differing agonist-independent activity. Mol Pharmacol 49:422-429.

Ruat M, Traiffort E, Arrang JM, Leurs R, and Schwartz JC (1991) Cloning and tissue expression of a rat histamine $\mathrm{H}_{2}$-receptor gene. Biochem Biophys Res Commun 179:1470-1478.

Samama P, Cotecchia S, Costa T, and Lefkowitz RJ (1993) A mutation-induced activated state of the $\beta_{2}$-adrenergic receptor. Extending the ternary complex model. J Biol Chem 268:4625-4636.

Seifert R, Lee TW, Lam VT, and Kobilka BK (1998a) Reconstitution of $\beta_{2}$ 
adrenoceptor-GTP-binding-protein interaction in Sf9 cells: high coupling efficiency in a $\beta_{2}$-adrenoceptor- $\mathrm{G}_{\mathrm{s}} \alpha$ fusion protein. Eur $J$ Biochem 255:369-382.

Seifert R and Wenzel-Seifert K (2002) Constitutive activity of G-protein-coupled receptors: cause of disease and common property of wild-type receptors. NaunynSchmiedeberg's Arch Pharmacol 366:381-416.

Seifert R, Wenzel-Seifert K, Bürckstümmer T, Pertz HH, Schunack W, Dove S, Buschauer A, and Elz S (2003) Multiple differences in agonist and antagonist pharmacology between human and guinea pig histamine $\mathrm{H}_{1}$-receptor. J Pharmacol Exp Ther 305:1104-1115.

Seifert R, Wenzel-Seifert K, and Kobilka BK (1999) GPCR-G $\alpha$ fusion proteins: molecular analysis of receptor-G-protein coupling. Trends Pharmacol Sci 20:383389.

Seifert R, Wenzel-Seifert K, Lee TW, Gether U, Sanders-Bush E, and Kobilka BK (1998b) Different effects of $\mathrm{G}_{\mathrm{s}} \alpha$ splice variants on $\beta_{2}$-adrenoreceptor-mediated signaling. The $\beta_{2}$-adrenoreceptor coupled to the long splice variant of $\mathrm{G}_{\mathrm{s}} \alpha$ has properties of a constitutively active receptor. J Biol Chem 273:5109-5116.

Smit MJ, Timmerman H, Blauw J, Beukers MW, Roovers E, Jacobs EH, Hoffmann $\mathrm{M}$, and Leurs $\mathrm{R}$ (1996) The $\mathrm{C}$ terminal tail of the histamine $\mathrm{H}_{2}$ receptor contains positive and negative signals important for signal transduction and receptor down-regulation. $J$ Neurochem 67:1791-1800.

Swaminath G, Xiang Y, Lee TW, Steenhuis J, Parnot C, and Kobilka BK (2004) Sequential binding of agonists to the $\beta_{2}$ adrenoceptor. Kinetic evidence for intermediate conformational states. J Biol Chem 279:686-691.

Traiffort E, Vizuete ML, Tardivel-Lacombe J, Souil E, Schwartz JC, and Ruat M (1995) The guinea pig histamine $\mathrm{H}_{2}$ receptor: gene cloning, tissue expression and chromosomal localization of its human counterpart. Biochem Biophys Res Com mun 211:570-577.

Visiers I, Ebersole B, Dracheva S, Ballesteros JA, Sealfon S, and Weinstein H (2002) Structural motifs as functional microdomains in G-protein-coupled receptors: Energetic considerations in the mechanism of activation of the serotonin 5- $\mathrm{HT}_{2 \mathrm{~A}}$ receptor by disruption of the ionic lock of the arginine cage. Int J Quantum Chem 88:65-75.

Wenzel-Seifert K, Liu HY, and Seifert R (2002) Similarities and differences in the coupling of human $\beta_{1^{-}}$and $\beta_{2}$-adrenoceptors to $\mathrm{G}_{\mathrm{s} \alpha}$ splice variants. Biochem Pharmacol 64:9-20.

Wenzel-Seifert K and Seifert R (2003) Functional differences between human formy peptide receptor isoforms 26, 98, and G6. Naunyn-Schmiedeberg's Arch Pharmacol 367:509-515.

Xie SX, Ghorai P, Ye QZ, Buschauer A, and Seifert R (2006a) Probing ligand-specific histamine $\mathrm{H}_{1}$ - and $\mathrm{H}_{2}$-receptor conformations with $N^{\mathrm{G}}$-acylated imidazolylpropylguanidines. J Pharmacol Exp Ther 317:139-146.

Xie SX, Kraus A, Ghorai P, Ye QZ, Elz S, Buschauer A, and Seifert R (2006b $N^{1}$-(3-Cyclohexylbutanoyl)- $N^{2}$-[3-(1H-imidazol-4-yl)propyl]guanidine (UR-AK57), a potent partial agonist for the human histamine $\mathrm{H}_{1^{-}}$and $\mathrm{H}_{2}$-receptors. J Phar macol Exp Ther 317:1262-1268.

Address correspondence to: Dr. Roland Seifert, Department of Pharmacology and Toxicology, University of Regensburg, Universitätsstraße 31, D-93053 Regensburg, Germany. E-mail: roland.seifert@chemie.uni-regensburg.de 